Journal of Original Studies

Cilt / Volume 1, Say1 / Issue 2, 2020, pp. 61-84

E - ISSN: 2717-719X

URL: https://journals.gen.tr/jos

DOİ: https://doi.org/10.47243/jos.1.2.06

Araştırma Makalesi / Research Article

\title{
ILKOKUL VE ORTAOKULLARIN OKUL YERİ DURUMLARI VE OKUL BAHÇESİ OLANAKLARI
}

\author{
SCHOOL LOCATION SITUATIONS AND FACILITIES IN SCHOOL \\ GARDENS OF PRIMARY AND SECONDARY SCHOOLS
}

\author{
Mustafa Aydın BAŞAR * \\ * Dr., Öğretim Üyesi, Çanakkale Onsekiz Mart Üniversitesi, Eğitim Fakültesi, \\ Eğitim Yönetimi ve Denetimi ABD, TÜRKIYY, e-mail: mbasar@comu.edu.tr \\ ORCID ID: https://orcid.org/0000-0003-3678-4647
}

Geliş Tarihi: 6 Temmuz 2020; Kabul Tarihi: 22 Temmuz 2020

Received: 6 July 2020; Accepted: 22 July 2020

\begin{abstract}
$\ddot{O Z Z E T}$
Okul yeri ve bahçeleri olumlu davranışların gelişstirilmesi için önemli ortamlardır. 15 yll önce yapılan bir çalışmada ilköğretim okullarının bu olanaklar bakımından yetersiz bulunduğu saptanmıştır. Tarama modelinde ele alınan çalışmanın amacı, 15 yll öncesine kıyasla, ilkokul ve ortaokulların okul yeri durumlart ve okul bahçesi olanakların saptamak ve okul bahçelerinin nasıl düzenlenmesi gerektiğini ortaya koymaktır. Çalışmanın bulguları, 15 yıl öncesine kıyasla, ilköğretim okullarının yeri ve bahçe olanakları bakımından sorunların büyük ölçüde devam ettiğini ortaya koymaktadır. Illkokul ve ortaokulların bahçelerinde tören, dinlenme ve oyun alanları, çim ve ağaçlık türü yeşil alanlar, uygulama bahçesi, eğitime yardımcı yerler bakımlarından da olanaksızlıklar yaşanmaktadır. Çalışmanın sonunda, okul bina yeri seçiminde çevresel koşulların önceden iyi saptanması; özellikle yeni yapılacak yapıların çă̆daş mimari, eğitimdeki gelişmeler ve yaklaşımlara uygun olarak düzenlenmesine yönelik öneriler geliş̧tirilmiştir.
\end{abstract}

Anahtar Kelimeler: Okul bahçesi, oyun alanlarl, okul çevresi, okul yeri, ilkokul ve ortaokul

\section{ABSTRACT}

School gardens are the important atmospheres for developing positive behaviors. In a study conducted 15 years ago it's defined that elementary school are inadequate for these facilities. In the research dealt with the model of survey, the aim of this study is to determine the possibilities of the school gardens and to show how school gardens should be organized compared to 15 years ago. Findings of the study reveal that problems of the primary and secondary schools in terms of the place and the garden facilities continue to a great extent compared to 15 years ago. The gardens of primary and secondary schools don't have possibilities of ceremony, relaxation and game fields, grass and woodened type of green areas, application gardens and educational supportive places. At the end of the study, pre-determination of environmental conditions in the locations of school buildings, and the new buildings should be arranged as contemporary, architectural and according to the educational developments and approaches.

Keywords: School garden, playground, the school surrounding, school location. 


\section{GİRIŞ}

Bir okulun amaçlarını gerçekleştirebilecek bir yapıya ulaşabilmesi için alt sistemleriyle birlikte bir sistem bütünlüğüne kavuşması ve uygun nicelik ve yeterlikte girdiler alması gerekmektedir. Okulun yönetim alt sistemlerinin iyi kurulması; örgütsel başarı için gerekli öğelerin etkili, verimli ve uyuşum içinde bir araya getirilmesi ve etkin olarak çalıştırılmasına bağlıdır (Can, 1991). Okullar, diğer örgütlerden farklı özellikleri içinde taşıyan özel yerlerdir ve farklı bir yönetim anlayışının yaşama geçirilmesini zorunlu kılarlar. Okul ortamlarında olan her şey, gerçekte, toplumdaki diğer kuruluşlarda olmayan eşsiz ahlaki değerler taşır (Sergiovanni, 1995). Bu anlamda okullar, öğrencilerin sadece temel yeteneklerinin ve becerilerinin geliştirildiği yerler değil; duyuşsal davranışların, değerlerin ve tutumlarının da kazandırıldığı yerlerdir.

Eğitim yeri ve ortamlarının yönetimi, diğer yönetim alanları kadar önemlidir (Başaran, 1982). Bir eğitsel ortam olarak okul ve bahçesinin çocuklar için çekici kılınması gerektiği fikri çok eskilere uzanmaktadır. Pestalozzi'nin, "sınıf çocuğun oturma odasıdır" sözünden hareketle, "okulun bahçesi de onun dinlenme ve oyun yeridir" denilebilir (Gollwitzer vd, 1959: 5). Okullar, kuruldukları yerler, bahçeleri, binaları ve sınıf düzenlemeleri ile eğitime bakışımızı ve eğitim kültürümüzü de yansıtırlar (Karip, 2002). Bir okulda eğitimin kalite ve başarısını bahçesinin temizliğinden, düzeninden, iyi kullanılmasından ve bahçeyi çevreleyen kuşatma alanlarından kestirmek olanaklıdır (Alparslan, 1993).

Öğrencinin içinde yaşadığı ve çalıştığı çevre, onun tüm davranışlarını etkiler. Çocuklar fiziksel, biyolojik ve toplumsal çevredeki koşullara, büyüklere göre daha duyarlıdır ve çevrede meydana gelen değişmelerden önemli boyutlarda etkilenmektedirler (Güler ve Çobanoğlu, 1994; Uz ve Sur, 1997). Okullarda sağlıklı bir eğitimin yapılabilmesi için, sağlıklı bir ortamın yaratılması önemli bir koşuldur. Okulun seçildiği yerin özelliklerinden, okul binalarının yapısal özelliklerine; okul bahçesindeki düzenlemelerden, derslik ya da bina içi bir köşenin düzenlenmesine kadar ergonomik öğeler gözetilmeli; eğitsel, estetik bir değer taşımasına özen gösterilmelidir (Iş11, 1991; Stephen ve Crawley, 1994).

Okulun fiziksel çevresinde yapılacak her türlü düzenlemeler öğrenci üzerinde psikolojik etkilerde bulunacaktır. Bu çevresel düzenlemeler, öğrenme ve gelişmeye yönelik çabaları ya cesaretlendirecek ve artıracak ya da önleyecek veya cesaret kırıcı olabilecektir (Kleberg, 1998). Sağlıkl1, doğru ve güzel hazırlanan ortamlarda öğrenim gören öğrencilerin iyiyi, güzeli ve doğruyu öğrenmeleri çok daha kolay olacaktır (Sağlıkova, 1990). Fiziksel ortamların çekiciliği ve içaçıcı biçimde düzenlenmesi öğrenci ve işgörenlerin güdülenmesi ve başarılarında katkı sağlayacağı gibi, örgüt kültürünün olumlu yönde gelişimine de katkı sağlayacaktır (Şafak, 1998).

\subsection{Okul yerleri ve özellikleri}

Okul binalarının yer seçimi ve yapımında çocuğun kendisi esas ölçü olmalı, okul yeri ve yapısının konumu öğrenciye uygun olmalıdır. Okulun öğrenci aldığı çevre, bir okulun kapladığı coğrafya olarak tanımlanabilir. Okul binası yapılacak yerin belirlenmesinde, kurulacak yerin nüfus büyüklügü ve öğrenci aldığı çevrenin özellikleri temel belirleyicilerdir. Okul, herşeyden önce öğrencilerin kolayca ulaşabilecekleri bir yerde olmalıdır. Bunun yanında, öğrencilerin yaşı, okulun sunabileceği ulaşım, beslenme, iklim özellikleri vb. olanaklar dikkate alınmalıdır (Chau, 1989; Unesco, 1983; Hallak, 1976, akt. Karakütük, 1994; Çetiner, 1972; Hesapçığlu ve Meriç, 1994). Öncelikle kurulduğu çevrenin eğitim gereksinimlerini karşılamakla sorumlu olan okulun inşa edileceği yerin, yoğun yerleşim bölgeleri olması ve çevre nüfusunun okul yapımına gereksinim yaratacak sayıda ve nitelikte olması gerekmektedir. Okul, fiziksel, psikolojik ve toplumsal yönden de sağlıklı bir çevrede kurulmuş olmalıdır. Okulun çevresinde bulunan bazı doğal ve örgütlü ortamlar, okulun eğitsel etkinliklerini 
engelleyeceği gibi öğrencilerin etkileşimleri yoluyla, onlarda istenmeyen davranışların gelişmesine de neden olabileceği unutulmamalıdır. İlkokul ve ortaokulların kurulacakları yerler konusunda dikkat edilmesi gereken özellikler şöyle sıralanabilir:

1. Okulun yapılmasının düşünüldüğü yerleşim biriminin demografik özellikleri öncelikle dikkate alınmalıdır (Karakütük, 1994: 73).

2. Bölgenin imar durumu ve imar planları, altyapı olanakları incelenmeli ve olanaklar ve geliştirilmesi konularında ilgili birim yönetimleriyle ortaklaşa çalışılmalıdır (Karakütük, 1994; Ergen 1986).

3. Okullarının kurulacağı yerler, okuldan yararlanacak öğrencilerin, evden yaklaşık olarak 10-15 dakikalık bir yürüyüş mesafesi olan 500 - 1200 metre arası bir uzaklıkta olmalı ve olabildiğince, yaya ulaşımı şeklinde okula ulaşılmalıdır (Karakütük, 1994; MEB, 1981).

4. Okul binalarının yapımı için fazla meyilli olmayan, su basması, deprem gibi doğal yıkımlardan korunabilecek, fay hatları vb. etmenlerden uzak; tehlikeleri yanında, sağlık açısından da zararı olacak çöplük, kanalizasyon, dere kenarı ve su kanallarına yakın olmayan güvenlikli alanlar tercih edilmelidir (Çetiner, 1972; Ergen 1986; Neufert, 1980; Sağlık Bakanlığı, 1992; TSE, 2000).

5. Okulun yeri saptanırken, o bölgenin iklimi, hakim rüzgarların yönü de dikkate alınmalıdır. İlköğretim okul arsaları fazla meyilli olmayan araziler olarak seçilmelidir. Kayalık, bataklık gibi doğal araziler ya uygun hale getirilmeli ya da bu yerlerden uzak olarak seçilmelidir. Arsa yapısı bitki yetiştirmeye uygun olmalıdır (Ergen 1986; Neufert, 1980: 229).

6. Okulun işlek ve gürültülü ana caddeler üzerine kurulmaması gerekir. Eğer ana cadde üzerine kurulma zorunluluğu varsa, giriş çıkış kapılarının ana caddeye değil, ara sokaklara veya boş araziye açılmasına yönelik düzenlemeler yapılmalıdır (Ergen 1986; Kayhan ve Eroğlu, 1997; Neufert, 1980).

7. Öğrenciler üzerinde olumsuz etki yapabilecek hapishane, meyhane, kıraathane, bar, pavyon, gazino, elektronik oyun merkezleri gibi halka açık yerler ile alkollü içki satılan yerler, okul yapı ve tesislerinden uzak bulunmalıdır. İlköğretim ve Eğitim Kanunu'nda (MEB, İEK Md. 60), eğitime olumsuz etkisi bulunabilecek ortamların okuldan en az 100 metre uzaklıkta bulunması gerektiği vurgulanmaktadır (Küçükahmet 1986; Kocaoluk 1996).

8. Okul yeri seçiminde, enerji, su ve kanalizasyon sistemlerinin elverişliliğine, yakın çevredeki trafik yoğunluğu ve konutlarda kullanılan enerji kaynakları ve yakma sistemlerinden ortaya çıkabilecek kirlilik miktarlarının yönelimine de bakılmalıdır. $\mathrm{Bu}$ nedenle, okul ile konutlar arasında belli bir uzaklık bulunmalıdır (Turner, 1970; Velicangil, 1975).

9. Okul arsası fiziksel, kimyasal veya biyolojik yönden kirlenmemiş veya kirlenme riski olmayan, gürültüden ve sağlığa zararlı toz, duman çıkaran, havayı ve doğayı kirleten sanayi kuruluşlarının etki alanlarından uzak bölgelerden seçilmelidir (Ergen 1986; Kayhan ve Eroğlu, 1997; Neufert, 1980).

10. Okulların itfaiye, karakol, hastane, ibadet yerleri gibi ortamlara yakın olması bazı yönlerden yararlı olmakla birlikte; siren sesleri nedeniyle, gürültülü ve dikkat dağıtıcı ortamlar oluşturması bakımından olumsuz etkiler de ortaya çıkarmaktadır. $\mathrm{Bu}$ ortamlar ile mezarlık, tren istasyonu ve havaalanı gibi fiziksel ve psikolojik zedelenme yapabilecek yerlerin okullardan uzak ya da olumsuz etki yaratmayacak konumda olması veya olumsuzluğun önlenmesi gerekir (MEB, 2008; 1981). 
Okul binasının bazı çevre koşullarından uzak olması istenirken, bazı örgüt ve birimlere de yakınlığı tercih edilmelidir. Öğrencinin eğitsel ve kişisel gereksinimlerini karşılayabileceği eczane, kırtasiye vb. alışveriş yerlerinin; ulaşımını kolaylaştıracak taşıt durakları ve trafik lambalarının okulun yakınında bulunması, ortaya çıkabilecek bazı sorunları önlemesi ya da çözüm getirmesi açısından yararlı görülmektedir. Bunun yanı sıra okul, eğitim sürecine katkıda bulunacak ya da okulun işleyişini kolaylaştıracak kütüphaneye, spor tesislerine, parklara ve diğer eğitim kurumlarına yakın olmalıdır. Bu yakınlık, varolan tesislerin, kaynakların ve araç gereçlerin ortak kullanımını sağlama ve paylaşma yararlarının yanında, ortak etkinliklerin planlanması açısından da yararlı olacaktır.

\subsection{Okul Bahçelerinde Eğitim ve Eğitime Yardımcı Ortamlar}

21. yüzyıl eğitimde birçok anlayışı farklı notalara taşımıştır. Gelinen noktada, öğrenme mekânları dersliklerle sınırlı görülmemekte; çevrenin ve koşulların fiziksel etkinliği olumlu yönde etkilediği ve okul bahçeleri eğitimin vazgeçilmez parçası olarak görülmektedir. Okul bahçeleri çocukların fiziksel gelişimleri yanında, zihinsel ve ruhsal gelişmelerine de katkı sağlayan sosyal mekânlardır. İşbirliğine dayalı öğrenme ve çalışma anlayışının egemen olduğu çağdaş bir toplumda; iyi donanımlı bir okul bahçesi, eğitimin ana karakterlerinden biridir. Aynı zamanda, yenilikçi okul bahçesi inşalarının, kentsel alanları simgelemesi açısından önemli olduğu söylenebilir (Lopez, Campbell ve Jennings, 2008)

Eğitimin sürekliliğinin sağlanması ve niteliğinin arttırılmasında önemli bir role sahip okul bahçeleri (Kaçan, Halmatov ve Kartaltepe, 2017) çocukların fiziksel, duygusal, sosyal, bilişsel, dil ve hareket gelişimi ile yaşamı öğrenmesinde büyük öneme sahip olan oyun (Özdemir 2009; Mangır ve Aktaş, 1993; Akt. Karasolak, 2009: 40) için okul bahçeleri öğrencilerin dersler ve dersler dışında yararlandıkları önemli alanlardır. Çocuğun kişiliğinin, yeteneklerinin, zihinsel ve bedensel becerilerinin geliştirilmesinde önemli katkısı bulunan okul bahçeleri (Aslan, 2010), öğrencilerin dinlenme saatlerinde yararlandıkları alanlar olmasının yanında, dersler ve eğitsel etkinliklerde de yararlanılacak ortamlardır. $\mathrm{Bu}$ ortamların, öğrencilerin eğitsel etkinliklerine, oyun oynamalarına, spor yapmalarına ve dinlenmelerine olanak verecek biçimde ağaçlandırılmış ve çimlendirilmiş yeşil alanlar, dinlenme ve oturma grubu, çardak, oyun parkı, açık ve kapalı spor alanları, yürüyüş ve bisiklet yolu, uygulama bahçesi, hava bilgi (meteoroloji) köşesi, kum havuzu, hayvanat bahçesi (Başar, 2003; Karasolak, 2009) çok amaçlı salon, tören alanı, Atatürk büstü ve bayrak direkleri geleneksel çocuk oyunları alanı, çiçek tarhı, açık derslik (MEB, 2011; 1992; 1985) ve anfi tiyatro, itfaiye yolu, servis ve personel otopark ve kontrol kulübesi (Algan, ve Uslu, 2009; Ramsey \& Rydeen, 1989) vb. eğitsel alanların yer alacağ 1 şekilde düzenlenmesi gerekir.

"Okul bahçeleri, sadece öğrencilere yönelik ortamlar olarak değil; çevresine de hizmet verecek ve örnek oluşturacak ortamlar olarak düşünülmelidir. Özellikle kentlerde yaşanan hızlı ve çarpık gelişmeler nedeniyle, kent planlamasında yeşil alanlara yeteri kadar yer verilmemiş ve kent çevre düzenlemelerinde sağlıksız ve yetersiz düzenlemeler ortaya çıkmıştır. $\mathrm{Bu}$ bakımdan, okul bahçelerinin bulunduğu çevreye de hizmet verecek şekilde planlanması ve düzenlenmesi, çevrenin yeşil alan gereksinimlerinin karşılanmasında ve okul çevre ilişkilerinin gelişmesinde önemli bir işlevin yerine getirilmesini sağlayacaktır. Fakat okullarımız çevreye hizmet sunmak bir yana, öğrencilerinin bu konudaki gereksinimlerini karşılamaktan bile bir hayli uzaktır. Birçok okul bahçesi, eğitsel ve dinlenme amaçlı düzenlemelerden yoksun olduğu gibi, öğrencilerin rahatça hareket edebilecekleri bir büyüklükte bile değildir. Bazı okullarda ise, daha önceleri geniş olan okul bahçeleri, öğrenci sayısındaki artışa paralel olarak, yapılan ek yapı ya da dersliklerden dolayı yetersiz duruma düşmüşlerdir" (Başar, 2003: 10-11). 
Tüm örgütler gibi eğitim örgütleri de, bir ya da daha fazla etmene dayanarak, normal çalışma işleyişinin bir parçası olarak yeni düşünceler yaratma ve onları uygulamaya koymak olan yenileşme sürecine (Schermerhorn, 1989) girerek eğitim politikalarını oluşturabilir ve yeni yapılanmalara gidebilir. Nitekim 100 y1la yaklaşan Türkiye Cumhuriyeti eğitim tarihinde birçok değişim ve yenileşme süreçlerinin yaşandığı görülecektir. Bunlardan, 1997 ve 2012 yıllarında okul sistemlerine yönelik olarak uygulamaya sokulan eğitim politikaları toplumda önemli tartışmalar yaratmıştır. 1946 yılında yapılan Üçüncü Milli Eğitim Şurası'nda ele alınan, zorunlu öğrenim süresinin 7-14 yaşları arasındaki çocuklar için sekiz yıla çıkarılması önerisi, 1961 yılında çıkarılan 222 sayılı İlköğretim ve Eğitim Kanunu'nda yer almış; ancak 1997 yılında yaşama geçirilebilmiştir. 2012 yılında sekiz yıllık kesintisiz zorunlu eğitim yerini 12 yıllık zorunlu kademeli eğitim okul sistemine bırakmıştır. Üç kademeye ayrılan yeni sistemde okullar; 4'er yıl süreli ilkokul, ortaokul ve lise olarak düzenlenmiştir (MEB, 2012). Sekiz yıllık kesintisiz zorunlu eğitim uygulamasında ilkokullar ve ortaokullar birleştirilmiş ve 6-14 yaş çocuklar aynı eğitim ortamlarında öğrenim görmüşlerdir. $4+4+4$ okul sistemi ile ise okullar ayrılarak, öğrenciler farklı eğitim ortamlarında eğitim görmeye başlamışlardır.

\section{3. İlgili Araştırmalar}

Okul bahçeleri ile ilgili olarak literatürde çok sayıda çalışma bulunmaktadır. Bunları büyük bölümü okul öncesi kurumların bahçe düzenlemeleri ile ilgilidir. Aşağıda, ilköğretim okulları ile ilgili çalışmalardan bazılarına yer verilmiştir:

Ereli’nin (2001), ilköğretim okullarının dış mekanlarına yönelik düzenleme ve planlama ilkelerinin ortaya konulduğu çalışmasında, dış mekanlardaki etkinlik alanlarının ilköğretim okullarının işlevlerine katkısı; ilköğretim çağındaki çocukların bedensel, sosyal, zihinsel ve psikolojik gelişimlerini destekleyen bu alanların özellikleri ele alınmıştır.

Kuş (2001) ise, Ankara İli Yenimahalle İlçesindeki farklı kademeden 80 okulun bahçesini, peyzaj mimarlığı açısından irdeleyerek sorunları ortaya çıkarmaya çalışmıştır. Çalışmada, okulların büyük bölümünde bahçelerin dar ve sadece tören alanları ile birkaç bitkisel materyalin bulunduğu, donanım açısından yetersiz olduğu gözlenmiştir. Hızla aryan öğrenci sayıları için çözüm olarak görülen ek binalarla bahçe alanının daha da daraldığı, spor alanları ve yeşil alanlara yeterince yer verilmediği belirlenmiştir. Bu olanaklarıyla birçok okulun bahçesinin öğretmen ve öğrenciler tarafından kullanıma uygun olmadığı saptanmıştır.

Dyment (2005), Kanada'da takip edilen beş okulda yöneticiler, öğretmenler ve velilerden (149 anket) elde edilen veriler doğrultusunda, okulların yeşil alanların olduğu ve bu alanların özellikle fen, beden eğitimi, dil eğitimi, matematik ve coğrafya gibi öğrenme-öğretme süreçlerinde düzenli olarak kullanıldığı bulunmuştur. Çalışmada; dış mekân alanlarını sınırlayan kurumsal, kültürel ve lojistik bir dizi engel de belirlenmiş, öğretme ve öğrenme için yeşil alan fırsatlarının tam olarak nasıl maksimize edilebileceğini de tartışılmıştır.

“Okul Öncesi Çocuk Eğitim Merkezlerinde İç ve Diş Mekan Organizasyonlarının Eğitim Yaklaşımları Çerçevesinde İncelenmesi” (Uysal, 2006) konulu ve çeşitli okul öncesi eğitim kurumlarına yönelik gözleme dayalı nitel araştırmada, okul öncesi eğitim kurumlarının değişebilir, dönüşebilir, esnek tasarımlara ihtiyacının olduğu ortaya konulmuştur.

Adana kent merkezinde 5 farklı bölgeden 10 resmi ilköğretim okulunda öğrenci, eğitimci ve okul aile birliği üyeleri ile karar verici ve uzmanlardan oluşan paydaşlara anketler uygulanarak taleplerinin belirlendiği çalışma (Algan ve Uslu, 2009) yapılmıştır. :Çalışmanın birinci aşamasında okulların fiziksel, kültürel ve var olan durum analizi yapılmış; ikinci aşamada ulusal ve uluslararası standartlar incelenmiştir. Okul bahçelerinde birçok eksik donatı elemanı tespit edilmiş, bu eksikliklerin giderilmesi için önerilerde bulunulmuştur. Son olarak 
da, elde edilen tüm veriler doğrultusunda iki okul bahçesi için kavramsal tasarı ve model olabilecek tasarım önerisi geliştirilmiştir.

Karasolak (2009) ise yaptığı çalışmasında, mimari özellikleri farklı üç ilköğretim okulundaki öğrenci ve öğretmenlerin okullarının bina ve bahçeleri hakkındaki görüşlerini ele almıştır. Araştırma sonuçlarına göre, okul bina ve bahçesinin genel görünümünün ve fiziki mekan uygunluğunun, eğitim-öğretim kalitesini etkilemede önemli bir faktör olduğu sonucuna ulaşılmıştır.

Blair (2010), okul bahçelerinin sağladığı yararların değerlendirilmesi ile ilgili araştırmasında, eğitimcilerin okul bahçelerini yaygın olarak kullandığını ancak ABD'deki araştırmacıların okul bahçelerinin kullanımına yönelik araştırmalarının sınırlı kaldığını belirtmiştir. Çalışmada, ABD eyaletlerinin sivil toplum kuruluşları ile işbirliğine giderek, okul bahçelerinin düzenlenmesinde hızlı bir artış gözlendiği vurgulanmıştır. Öğretmenler de bahçeleri öğrenme aracı gördüğü bulgularına ulaşılmıştır. Son 20 yılda uygulanan teşvik projeleriyle, okul bahçeciliği ulusal bir harekete dönüşmüştür.

Özdemir'in 2009 yılında yaptığı çalışmada, ilköğretim okulları bahçelerinin çocuk gelişimi ve sağlıklı yaşam üzerine etkilerinin irdelenmesi amaçlanmıştır. Ankara kentinde belirlenen beş ilköğretim okulunda toplam 290 üçüncü ve dördüncü sınıf öğrencisinin okul bahçeleri hakkındaki görüşleri, günlük okul aktiviteleri yanında okul yönetimi ve öğretmenlerinde görüşleri değerlendirilmiştir. Ayrıca belirlenen fiziksel aktivite değerleri ile okul bahçelerinin peyzaj özellikleri arasındaki ilişkiler tespit edilerek, bu alanların sağlıklı yaşamı desteklemesine yönelik hedefler belirlenmiştir.

Özdemir (2011), yaptığı uygulamalı çalışmasında, bir ilköğretim okul bahçesinin mevcut durumuna yönelik bir anket çalışması yapmıştır. Daha sonra okul müdürü, ilgili öğretmenler, okul aile birliği ve velilerine yönelik bir bilgilendirme toplantısı düzenlemiştir. Okulun öğrenci sayısı, yaş aralıkları, istekleri ve gereksinimleri dikkate alınarak değerlendirmeler yapılmıştır. Sonrasında, okul bahçesinde okula özgü, ekolojik ve eğitsel ilkeler doğrultusunda, teneffüs etkinliklerine yönelik alan kullanımı ve mekânsal önerileri içeren peyzaj tasarım projesi hazırlanmıştır. Özdemir, Çorakçı (2011) ile yaptığı diğer bir çalışmada ise okul bahçelerinin çocuk gelişimi ve sağlıklı yaşamı üzerine etkilerinin irdelenmesi ve çocuklarda çevre bilincinin geliştirilmesini amaçlamışlardır. Bunun için beş okulda öğrenci ve öğretmenlerin görüşleri alınmış, görüşler doğrultusunda okul bahçeleri yeniden tasarlanmıştır. Düzenlemeler sonunda, teneffüs boyunca aktif olan çocukların daha sağlıklı davranışlar sergiledikleri, büyük bölümünün geniş bahçeli okulları beğendikleri, peyzaj değerleri düşük okul bahçelerinden memnun olmadıkları bulgularına ulaşılmıştır. Çalışmanın sonuçları, planlı olarak düzenlenen daha yeşil ve bakımlı okul bahçelerinin; öğrencilerin çevreye bakışını ve oyun alışkanlıklarını değiştirerek fiziksel etkinliklere yönelimlerini desteklediğini, öğrencilerin katılımıyla sürdürülebilir okul ortamlarının oluşturulabileceğini ortaya koymuştur.

Şişman ve Gültürk (2011), Tekirdağ'daki çalışmalarında 6-15 yaş grubundaki çocukların fiziksel, ruhsal ve sosyal açıdan gelişmelerinde önemli bir yeri olan okul bahçelerinin durumu irdelenmiştir. Kent merkezinde bulunan 23 ilköğretim okulundan rastgele seçilen 11 ilköğretim okulu değerlendirilmiştir. Okul bahçeleri, yapısal ve bitkisel materyal açısından değerlendirilmiş mevcut durumları ortaya konularak eksiklikleri belirlenmiş ve öneriler geliştirilmiştir.

Aksu, Demirel ve Bektaş (2011), Trabzon'daki çalışmalarında ilköğretim okullarının “donatı elemanları ve okul bahçesi” konu olarak ele alınmıştır. İl merkezindeki 35 ilköğretim okulu bahçesinde gözlem ve incelemelerde bulunulmuş, donatı elemanlarına ilişkin mevcut durum değerlendirilmesi yapılarak fotoğraflarla örneklendirilmiştir. Yeterlilik düzeylerinin 
ortaya koyulması, uzman kişilerin (peyzaj mimarları) okul bahçelerinde yaptıkları gözlem ve incelemelere dayanmaktadır. Her okul için donatı elemanlarının yeterliliği işlev, sayı ve estetik yönünden ortaya koyulmuştur ve yetersiz bulunmuştur.

Isparta ilinde yapılan bir çalışmada (Akgül Gök 2012), ilköğretim öğrencilerinin hayallerindeki ideal okul bahçesi ile ilgili peyzaj öğelerini ve bunların kurum, konum, cinsiyet arasındaki farklılıkları ile sınıflar arasındaki değişimin belirlenmesi amaçlanmıştır. Sekiz ilköğretim okulunda, 2., 5. ve 8. sınıf öğrencilerinin hayallerindeki ideal okul bahçelerini belirlemek için "biliş haritalama" ve "anket" teknikleri kullanmıştır. Çalışma sonucunda özel okullar ile devlet okulları, kent çeperinde bulunan okullar ile kent merkezinde bulunan okullar, kız öğrenciler ile erkek öğrenciler ve sınıflar arasında istatiksel olarak anlamlı farklılıklar saptanmıştır. 2. sınıf öğrencileri okul bahçelerinde bitkiler, hayvanlar vb. gibi doğal elemanlar ile oyun elemanlarının bulunmasını tercih ederken, 5. ve 8. sınıf öğrencileri ise daha çok spor alanları, yapısal elemanlar, etkinlik alanları ve kantin, büfe, kafeterya gibi diğer kullanım alanlarını tercih etmişlerdir.

İstanbul'un Avrupa yakasındaki okul bahçelerinin mekânsal olarak analizi ve öğrenci sayısına göre yeterliliklerinin ulusal ve uluslararası standartlara göre belirlenmesi amaciyla Saka (2014) tarafindan yapılan çalışmada; okul bahçelerinin durumu haritalar kullanılarak belirlenmiştir. Okul bahçelerinin alanları ve metrekareye düşen öğrenci sayıları saptanmıştır. Buna göre, okullarda öğrenci başına $20 \mathrm{~m}^{2}$ yeterliliğini sağlayan okulların oranı $\% 5,7$ ve $5 \mathrm{~m}^{2}$ olan TSE standardını sağlayan okulların oranının ise \% 30,2 olduğu belirlenmiştir. Ulaşılan sonuçlar, tüm ilçelerde okulların bahçe alanlarının oldukça yetersiz olduğu göstermektedir.

Ürey (2018), Okul bahçeleri ile ilgili uygulamalara yönelik çalışmaların içerik analizlerini yapmış ve bahçe temelli öğrenme yaklaşımı eğilimlerini saptamaya çalışmıştır. 2000-2015 yılları arasında 21 dergide yayımlanan 162 makalenin, araştırmacının geliştirdiği "Okul Bahçesi Uygulamaları Alan Tarama Formu" kullanılarak, betimsel içerik analizi yapılmıştır. Analiz sonuçlarına göre, daha çok akademik performansın belirlenmesi ve geliştirilmesi ile birlikte sağlıklı yaşam becerilerinin geliştirilmesi hedeflendiği bulunmuştur. Nicel ve nitel veri toplama araçlarına yer verilen bu çalışmalar daha çok okul öncesi ve ilköğretim düzeyindeki öğrencilerle ilgilidir. Okul bahçesi çalışmalarında, öğrencilerin akademik performanslarının gelişimi, sağlıklı yaşam becerilerinin gelişimi, bireysel ve sosyal becerilerinin gelişimi üzerinde olumlu bir etkiye sahip olduğu tespit edilmiştir.

Birbirinden çok farklı olan iki uygulamayla, özellikle eğitsel mekanlar açısından önemli sorunlar ortaya çıkmış ya da var olan sorunlar daha da artırmıştır. Bu sorunların karşılaştırmalı olarak ele alınıp irdelenmesi; sorunların saptanması, doğru karar süreçlerinin işletilmesi ve nitelikli eğitim uygulamalarının yaşama sokulabilmesi açılarından önemlidir. Eğitim sorunlarının çözümlenmesi için farklı ülkelerdeki eğitim sistemlerini, bu sistemlerin eğitim sorunları ve nedenlerini, diğer toplumlardaki benzer etkenlere değinerek saptamayı ve yorumlamayı esas alan bir araştırma alanı (Neff, Lauwerys, Varış, 1979) olan karşılaştırmalı eğitimin kullandığı yönteminden yararlanarak; bir ülkenin eğitim alt sistemleri, farklı örgütlerin uygulamaları ya da bir örgütün aynı yönde fakat farklı dönemlerdeki karar ve uygulamaları da karşılaştırmalı olarak irdelenebilir. Karşılaştırmalı eğitim çalışmaları, eğitim politikasının analiz çalışmalarıyla özdeşleşmiş bir özellik gösterdiğinden, "Eğitim Politikası" çalışmaları olarak da algılanabilmektedir. Bu çalışmada, Türk Eğitim Sistemi eğitim politikaları doğrultusunda, 1997 ve 2012 yıllarında uygulamaya konulan okul sistemlerinin ortaya çıkardığ okul yerleri ve okul bahçeleri sorun ve uygulamaları karşılaştırmalı olarak ele alınmıştır. 


\subsection{Problem}

Eğitim sistemine katılan tüm çocukların nitelikli eğitim almaları önemlidir. Eğitim sistemleri, değişim ve glişmelere paralel olarak amaç ve yapılarında kendilerini yenileme yoluna gidebilirler. Bu değişiklik, sadece yapıyı kurma ile sınırlı kalmayıp donanım alt boyutunda da yenilenmeyi getirmelidir (Bursalığlu, 2019). Bu anlamda okul binaları ve okul bahçaleri ile bunların eğitime hizmet edecek şekilde donatılması gerekir. Okul alanları, uygulamalı öğrenme ortamları olarak çocukların kendilerini becerileriyle ifade edebileceği yerlerdir (Evergreen, 2001). Özellikle ilköğretim çocukları için önemli yerler olan nitelikli okul bahçeleri temel bir gerekliliktir. Açık hava etkinlikleri çocukların büyüme, sağlıklı yaşam, keyif alma ve iyi bir eğitim için kritik öneme sahiptir. Çocukların birlikte kararlaştırdığı kurallara ve kendi projelerine sahip yaratıcı araştırma ve deneyler yapma, doğayı keşfetme, oyunlar oynama, organize takım sporları yapma yerleridir. 21st Century School Fund (2011), çocukların, deneyler ve projeler yoluyla, doğal ortamlarında bulunan bitkilerin ve küçük hayvanların keşfedilmesine olanak sağlanması gerekliliğini vurgulamaktadır.

Okullarının kuruluş yeri, konumu ve okul bahçeleri bakımından durum ve yeterliğinin saptanması; daha kaliteli ve nitelikli bir eğitim ortamının oluşturulmasına yönelik öneriler geliştirilmesi önem taşımaktadır. Okullarının fiziksel olanaklar açısından geliştirilmesine yönelik çabalar gözlenmekle birlikte; bunlar, genellikle, sorun çözme sürecine dayanmadan, okul sistemini işleten okul yöneticisi ve öğretmenlerinin görüşleri yeterince alınmadan yapılmaktadır. Bu durum, gereksinimlerin karşılanmasında ya yetersiz kalınması ya da istenen nitelikte karşılanamaması sorunlarını ortaya çıkarmaktadır. Okul örgütlerinin eğitim yerleri ve okul bahçesi ile ilgili gereksinimlerinin istenen nitelik ve nicelikte karşılanması ve olanakların geliştirilmesi; bu yöndeki kararların verilere dayalı olması ve okul yöneticileri ile öğretmenlerinin görüsslerinin alınmasına bağlıdır. 15 yıl arayla iki farklı okul sistemi uygulamaları doğrultusunda, okulların okul yeri ve bahçesi olanaklarında nasıl bir gelişme yaşandığının belirlenmesi önemlidir. Çalışmadan elde edilen bulgular ve ulaşılan sonuçların, okullarının yeri ve okul bahçesi olanakları bakımından geliştirilmesi yönündeki çabalara bilimsel boyutta katkı sağlaması ve okulların eğitim olanaklarına ilişkin ileride yapılacak araştırmalara kaynaklık etmesi beklenmektedir.

\subsection{Amaç}

Çalışman amacı; resmi ilkokul ve ortaokulların okul yerinin uygunluğu ile okul bahçeleri olanaklarını saptamak, 15 yıl önceki çalışma sonuçlarıyla karşılaştırmaktır

$\mathrm{Bu}$ amaçla şu sorulara yanıt aranmıştır:

1. İlkokul ve ortaokulların okul yerleri ve uygunluğu bakımından durumu nasıldır?

2. İlkokul ve ortaokulların okul yerleri ve uygunluğu bakımından durumu 15 yıl öncesine göre farklı midır?

3. İlkokul ve ortaokul bahçelerinin; a) büyüklükleri, b) çevre duvarları, c) eğitsel alanları, d) eğitime destek yerleri olanakları bakımlarından durumu nasıldır?

4. İlkokul ve ortaokul bahçelerinin olanakları bakımlarından durumu 15 yıl öncesine göre farklı midır?

\section{YÖNTEM}

Araştırma, ilkokul ve ortaokulların okul yeri ve bahçelerinin durumunun belirlenmesi ve 15 yıl önceki durumla karşılaştırmasına dayalı olarak tarama modelinde desenlenmiş, süreli araştırma özelliğindedir. Çalışmada, okul yerinin durumu ve okul bahçelerindeki düzenlemeleri saptamaya yönelik olarak, karşılaştırma yapılan araştırmanın (2003) desenlemesinde izlenen yol esas alınmış ve tarama modeline dayalı bir düzenlemeye gidilmiştir. Çalışmanın, 15 yıl önce 
yapılan çalışmayla karşılaştırılmasında, bu süre içinde, ele alınan olguya ilişkin herhangi bir değişiklik olup olmadığını ya da gelişmeleri tespit edebilmek amacıyla, süreli araştırma ilkelerine dayalı bir düzenlemeye gidilmiştir (Altunışık ve diğerleri, 2010).

Çalışmada, Kalkınma Bakanlığı (2013) tarafından hazırlanan "illerin ve bölgelerin sosyo-ekonomik gelişmişlik sıralaması ilgili tablosunda beş ayrı tabakada yer alan illerden, tabakalı örnekleme yöntemiyle ve her bir tabakadan basit tesadüfü yolla belirlenen örneklem grubunda, toplam beş ilden 148 resmi ve özel ilköğretim okulu yer almıştır (MEB, 2016). İlkokul ve ortaokul olarak da her ilde eşit sayıda okul belirlenmiştir. Bu okullardan da envanterleri geri dönen ya da uygun şekilde doldurulan 119 okula ait envanter değerlendirmeye alınmıştır. Örneklemde yer alan okullarının kurulduğu yerin durumu, okul bahçesi olanakları, ilgili alanyazından yararlanılarak hazırlanan bir envanter ile saptanmaya çalışılmıştır.

Tablo 1. Çalışma evreni ve örneklem grubu ilköğretim okullarının sayıları

\begin{tabular}{clcccccc}
\hline \multirow{2}{*}{$\begin{array}{c}\text { İl Gelişmişlik } \\
\text { Düzeyi }\end{array}$} & İller & \multicolumn{2}{c}{$\begin{array}{c}\text { Evrendeki Okul } \\
\text { Sayısı }\end{array}$} & \multicolumn{2}{c}{$\begin{array}{c}\text { Örnekleme Giren } \\
\text { Okul Sayısı }\end{array}$} & \multicolumn{2}{c}{$\begin{array}{c}\text { Değerlendirmeye } \\
\text { Alıan Envanter } \\
\text { Sayısı }\end{array}$} \\
\cline { 2 - 7 } & & $\mathbf{2 0 0 3}$ & $\mathbf{2 0 1 8}$ & $\mathbf{2 0 0 3}$ & $\mathbf{2 0 1 8}$ & $\mathbf{2 0 0 3}$ & $\mathbf{2 0 1 8}$ \\
\hline 1 & İstanbul & 1.500 & 1.522 & 125 & 56 & - & 46 \\
2 & Kırklareli & 178 & 167 & 23 & 12 & - & 11 \\
3 & Manisa & 788 & 841 & 60 & 36 & - & 28 \\
4 & Aksaray & 287 & 361 & 27 & 20 & - & 16 \\
5 & Kars & 412 & 540 & 38 & 24 & - & 18 \\
\cline { 2 - 7 } GENEL TOPLAM & 3.165 & 3.431 & 373 & 148 & 292 & 119 \\
\hline
\end{tabular}

Karşılaştırmalı bir çalışma olan bu araştırmanın desenlenmesinde, sağlıklı kıyaslamaların yapılabilmesine dönük bir yapının oluşturulmasına özen gösterilmiştir. Çalışma; 2003 ve 15 yı1 sonrasında yapılan çalışmanın örneklem grubu benzeştiği, veri toplama aracının amaca hizmet ettiği sayıltıları üzerine kurulmuştur. Bu yönüyle, 2003 yılında ve yapılan son çalışmanın araştırma desenleri, bulgu, yorum ve sonuçlarının karşılaştırmalar yapılmasına olanak verecek bir yapıda olduğu varsayılmıştır. Her iki çalışmada da veriler, okul sistemlerindeki değişiklik kararlarının alınmasından beş yıllık bir süreç tamamlandıktan sonra toplanmıştır. Bulgular ve sonuçların açıklanmasında, yapılan ilk çalışma için "2003 yılı" ve son çalışma için ise "2018 yılı" şeklinde bir adlandırma yapılmıştır. Bulguların betimlenmesinde öncelikle son çalışmaya ilişkin açıklamalara yer verilmiş, ardından 2003 yılı bulgularıyla karşılaştırılmıştır.

\section{BULGULAR}

Bu başlık altında, çalışmanın alt amaçlarına doğrultusunda, ilköğretim okullarının okul yeri durumu ve dış kapılar ve açıldıkları yerler ile okul bahçelerinin büyüklüğü, çevre (kuşatma) duvarı, eğitsel ve eğitime yardımcı yerler bakımlarından durumları ortaya konulmaya çalış1lmıştır. Bütünlük oluşturması açısından 1. ve 2. alt amaç ile 3. ve 4. amaçlara ilişkin bulgular birlikte ele alınmıştır.

\section{1. İlköğretim Okul Yerleri ve Uygunluğuna İlișkin Bulgular}

İlköğretim okulllarının bulunduğu yerler ve konumlarının uygunluğu ile ilgili olarak; okul ve 100 metrelik çevresinin durumu, okulların öğrencilerini aldıkları mesafe ve okul bahçe ve bina kapılarının çevreye açılım durumlarına bakılmıştır.

Tablo 2 incelendiğinde, son çalışmanın verilerine göre, ilköğretim okullarının dörtte üçünden fazlasının $(\%$ 79,0) yerleşim birimlerinde ve konutlar arasında yer aldığ1 görülmektedir. Bu okulların birçoğu da konutların aralarına sıkışmış veya içiçe durumdadırlar. Okulların yüzde 25,2 (30 okul)'sinin 100 metrelik çevresinde ibadet yerleri, yüzde 17,6 (21 okul)'sının yakınında taşıt durakları, yüzde 15,1 (18 okul)'inin etrafinda oyun ve park alanları, 
yüzde 9,2 (11 okul)'sinin yakınında spor tesisleri ve yüzde 3,4 (4 okul)'ünün yararlanabileceği yakınlıkta da kütüphane bulunmaktadır. Bunun yanında, ilköğretim okullarının 100 metrelik yakınında bulunmaması yasal metinlerle de ortaya konmuş kahvehane, meyhane, bar, gazino vb. eğlence yerleri (\% 14,3), çıkardıkları gürültü, duman ve zehirli gazlarla eğitimi ve öğrencileri olumsuz etkileyecek işyeri ve fabrikalar $(\% 2,5)$ bulunmaktadır.

Tablo 2. İlköğretim okullarının 100 metre çevresinin özellikleri

\begin{tabular}{|c|c|c|c|c|}
\hline \multirow[t]{2}{*}{ Özellikler } & \multicolumn{2}{|c|}{2003 Yilı } & \multicolumn{2}{|c|}{2018 Yilı } \\
\hline & $\mathbf{n}$ & $\%$ & $\mathbf{n}$ & $\%$ \\
\hline Konutlar arasındadır. & 210 & 71,9 & 94 & 79,0 \\
\hline Cami, kilise vb. ibadet yerleri vardır. & 78 & 26,7 & 30 & 25,2 \\
\hline Taşıt durakları vardır. & 57 & 19,5 & 21 & 17,6 \\
\hline Yerleşim birimine uzaklı̆̆ 200 metreden fazladır. & 48 & 16,4 & 12 & 10,1 \\
\hline Oyun alanları, park vardır. & 40 & 13,7 & 18 & 15,1 \\
\hline Kahvehane, meyhane, bar, gazino vb. tesisler vardır. & 36 & 12,3 & 12 & 10,1 \\
\hline Çöplük, kanalizasyon, dere kenarı veya su kanalı yakınındadır. & 30 & 10,3 & 7 & 5,9 \\
\hline Spor tesisleri vardır. & 25 & 8,6 & 11 & 9,2 \\
\hline Kütüphane vardır. & 14 & 4,8 & 4 & 3,4 \\
\hline Eğitimi olumsuz etkileyen işyerleri ve fabrikalar vardır. & 9 & 3,1 & 3 & 2,5 \\
\hline Otobüs terminali, tren istasyonu, havaalanı vardır. & 6 & 2,0 & 2 & 1,7 \\
\hline Deniz kenarındadır. & 6 & 2,0 & 2 & 1,7 \\
\hline Baz istasyonu vardır. & - & - & 3 & 2,5 \\
\hline Başka & 29 & 9,9 & 8 & 6,7 \\
\hline
\end{tabular}

Üç okulun yakınında ise insan sağlığını doğrudan ve olumsuz biçimde etkileyecek baz istasyonu vardır. Olumlu etkileri yanında, iyi işletilip denetlenmediğinde okul işleyişini olumsuz etkileyebilecek otobüs terminali, tren istasyonu, havaalanı gibi ulaşım yerleri, iki (\% $1,7)$ okulun yakınında bulunmaktadır. Yine aynı sayıda okul da deniz kenarında yer almaktadır. Bir okul da koruluk bitişiğindedir. 10 ilköğretim okulu (yüzde 16,4) da yerleşim birimlerine 100 ve daha fazla uzaklıktadır. Başka seçeneğinde yer alan okulların yakınında resmi kurumlar, karakol, askeri tesisler vb. bulunmaktadır.

Ulaşılan bulgular, 15 yıl önceki araştırma bulgularıyla karşılaştırıldığında, konutlar arasında kalan okul sayısındaki artış; taşıt durakları, kahvehane, meyhane vb. yakınındaki okullar ile yerleşim birimleri uzağındaki okullarda azalma dikkat çekmektedir. Bulgular, geçmişte olduğu gibi geçen onbeş y1llık süre içinde okul yeri ve konumuna ilişkin eğitim amaç ve ilkelerini dikkate alan bir politika ya da uygulamanın geliştirilmediğini göstermektedir.

Okulların, öğrencilerin okul yaşamlarını olumsuz etkilemeyecek bir mesafede olması önemlidir. Aşağıdaki Tablo 3'te görüleceği gibi günümüzde, okullarının üçte biri $(\% 33,6)$ öğrencilerin yaşamlarını sürdürdükleri konutlara 501 - 1.000 metre arasında bir uzaklıkta bulunmaktadır. İlköğretim okulları için iki kilometreye kadar mesafenin kabul edilebilir uzaklık olduğu düşünüldüğünde, okulların yüzde 56,3'ünün öğrencilerin yaya olarak gitmelerine olanak tanıyabilecek bir yerde bulundukları ortaya çıkmaktadır. Okullarının yüzde 43,7'si yaya olarak ulaşılabilecek mesafenin ötesindeki yerlerden öğrenci almaktadırlar. İlköğretim okullarının yüzde 14,3'ü ise beş kilometreden daha uzakta bir mesafeden okullarına gelip gitmektedirler. İlköğretim okullarına devam eden öğrencilerin sadece 12 (\% 10,1)'si okullarına 500 metre ve daha yakın bir mesafede oturmaktadırlar.

2003 yılında yayınlalan araştırmanın bulguları ile son çalışmanın verilerine dayalı olarak ulaşılan bulgular arasından bir paralellik görülmektedir. 15 yıl öncesine göre, 5.000 
metre ve altında mesafeden öğrenci alan okullar artış gösterirken, 5.000 metrenin üzerinde mesafeden öğrenci alan okullar azalmış ve yüzde 25,4'ten 14,3'e düşmüştür.

Tablo 3. İlköğretim okullarının öğrenci aldığı konutlarla mesafesi

\begin{tabular}{rcrrr}
\hline \multirow{2}{*}{ Okul Mesafesi } & \multicolumn{2}{c}{$\mathbf{2 0 0 3}$ Yılı } & \multicolumn{2}{c}{$\mathbf{2 0 1 8}$ Yilı } \\
\cline { 2 - 6 } & $\mathbf{n}$ & $\mathbf{\%}$ & $\mathbf{n}$ & $\mathbf{\%}$ \\
\hline 500 metreye kadar & 17 & 5,8 & 8 & 6,7 \\
$501-1.000$ & 83 & 28,4 & 40 & 33,6 \\
$1,001-2.000$ & 33 & 11,3 & 16 & 13,4 \\
$2.001-3.000$ & 22 & 7,6 & 11 & 9,3 \\
$3.001-4.000$ & 36 & 12,3 & 17 & 14,3 \\
$4.001-5.000$ & 24 & 8,2 & 10 & 8,4 \\
5.001 ve yukaris1 & 74 & 25,4 & 17 & 14,3 \\
Yanit Vermeyenler & 3 & 1,0 & - & - \\
TOPLAM & 292 & 100,0 & 119 & 100,0 \\
\hline
\end{tabular}

Okulların, biri ön, diğeri arkada en az iki giriș kapısının bulunması gerekir. Ön kapının araç girişine de olanak verecek, ancak sadece öğrenci, işgörenler ve ziyaretçilerin girecekleri; arka kapı ise, araçların sürekli girişine de uygun olacak şekilde düzenlenmelidir (Wallace, 1992). Araç girişinin arka kapıdan yapılması özellikle öğrenci güvenliği açısından önemlidir. Bahçe içinde araçların kullanacakları yollar da, öğrencilerin yoğun bulunduğu oyun ve dinlenme alanlarına uzak olmalıdır. Okul ana giriş kapılarının ana caddelere ve işlek sokaklara açılmaması ya da doğrudan açılmaması gerekir.

Tablo 4. İlköğretim okulları dış kapılarının açıldığı yerler

\begin{tabular}{lrrrr}
\hline & \multicolumn{2}{c}{$\mathbf{2 0 0 3}$ Yılı } & \multicolumn{2}{c}{$\mathbf{2 0 1 8}$ Yılı } \\
\cline { 2 - 5 } & $\mathbf{n}$ & $\mathbf{\%}$ & $\mathbf{n}$ & $\mathbf{\%}$ \\
\hline Ara sokaklara & 131 & 44,9 & 61 & 51,3 \\
Ana caddeye & 107 & 36,6 & 46 & 38,7 \\
Ana cadde - ara sokaklara & 18 & 6,2 & 10 & 8,4 \\
Ana cadde - boş arsa & 3 & 1,0 & 1 & 0,8 \\
Başka & 28 & 9,6 & 1 & 0,8 \\
Yanıt vermeyenler & 5 & 1,7 & - & - \\
\multicolumn{1}{r}{ TOPLAM } & 292 & 100,0 & 119 & 100,0 \\
\hline
\end{tabular}

Tablo 4 incelendiğinde, ilköğretim okullarının dış çevre ile bağlantısının kurulduğu kapılarının yüzde 51,3'ünün ara sokaklara, yüzde 38,7'sinin ana caddelere açıldı̆̆ görülmektedir. 10 okulun $(\% 8,4)$ ise dış kapıları hem ana caddeye, hem de ara sokaklara açılmaktadır. Sadece bir $(\% 0,8)$ okulun da hem caddeye hem de boş arsaya açılan kapıları bulunmaktadır. İlköğretim okullarının dışa açılan kapılarının birden fazla olduğu düşünülürse, yüzde 43,8'inde doğrudan ana caddeye açılan kapı bulunduğu; aynı şekilde ara sokaklara açılan dış kapıların da yüzde 51,1 olduğu söylenebilir. Son çalışmanın bulguları ile 2003 yılındaki çalışmanın bulguları benzerlik görülmekle birlikte, ara sokaklara açılan kapısı bulunan okullar arttış göstermiştir. Bu artışın daha çok yeni kurulan okulların kuruldukları yerler ile ilgili olduğu söylenebilir. Ara sokakla açılan okul kapıların artış göstermesi okulların güvenliği açısından olumlu bir gelişmedir.

Her iki çalışmada, okul bahçe kapılarının açıldığı yerler yanında, okul binalarının doğrudan dışarıya açık olma durumlarına da bakılmış ve bunlara ilişkin veriler Tablo 5 'te verilmiştir. 
Tablo 5. İlköğretim okul binalarının doğrudan caddeye ve sokaklara açılan kapılarının varlığı

\begin{tabular}{lrrrr}
\hline & \multicolumn{2}{c}{$\mathbf{2 0 0 3}$ Yılı } & \multicolumn{2}{c}{$\mathbf{2 0 1 8}$ Yılı } \\
\cline { 2 - 5 } Varlık Durumu & $\mathbf{n}$ & $\mathbf{\%}$ & $\mathbf{n}$ & $\mathbf{\%}$ \\
\hline Yok & 194 & 66,4 & 96 & 80,7 \\
Var & 92 & 31,5 & 23 & 19,3 \\
Tehlike yarattl. & 29 & 31,5 & 8 & 34,8 \\
Tehlike yaratmadl. & 63 & 68,5 & 15 & 65,2 \\
Yanit vermeyenler & 6 & 2,1 & - & - \\
$\quad$ TOPLAM & 292 & 100,0 & 119 & 100,0 \\
\hline
\end{tabular}

Okul bahçelerinin olduğu gibi okul binalarının da doğrudan cadde ya da sokaklara açılan kapılarında önemli bir azalma belirlenmiştir. İlköğretim okul binalarının yaklaşık beşte birinin (\% 19,3), doğrudan caddeye açılan kapıya sahip bulunduğu saptanmıştır (Tablo 5). 96 ilköğretim okul binasının (\% 80,7) ise, doğrudan caddeye açılan kapısı bulunmamaktadır. Doğrudan caddeye açılan kapısı bulunan 23 okul binasından sekizinde $(\% 34,8)$ bu durumun öğrenciler açısından tehlike yarattığı, öğrencilerin trafik kazası vb. sorunlar yaşadığı, okul yöneticilerince ifade edilmiştir.

Okul bahçesinde öğrenci başına düşecek alan en az beş metrekare olmalıdır. En küçük bahçe alanı ise, en az $400 \mathrm{~m}^{2}$ olmalıdır (Neufert, 1980, s. 229; Neufert, 1977; Ergen,1986; Küçükahmet, 1986; Kocaoluk, 1983; Thrower; MEB, 1992). Ancak, ilköğretim okullarının bu değerlerin altında bir bahçe alanına sahip oldukları gözlenmiştir. Toplanan veriler, 2003 yılında yapılan çalışmada ilköğretim okullarında öğrenci başına $3,8 \mathrm{~m}^{2}$ alan düştüğünü, $17(\% 5,8)$ ilköğretim okulunda bahçe alanı $400 \mathrm{~m}^{2}$ 'nin altında kaldığını ortaya koymaktadır. Son çalışmada ise okul bahçelerinde öğrenci başına düşen alanda $\left(3,2 \mathrm{~m}^{2}\right)$ ve $400 \mathrm{~m}^{2}$ altında kalan okullarda azalma olduğu bulunmuştur.

Tablo 6. İlköğretim Okulları Bahçelerinde Öğrenci Başına Düşen Alan Büyüklükleri

\begin{tabular}{cccc}
\hline \multicolumn{2}{c}{2003 Yılı } & \multicolumn{2}{c}{2018 Yılı } \\
\hline $\begin{array}{c}\mathbf{4 0 0} \mathbf{~ m}^{\mathbf{2}} \text { altında } \\
\text { bahçesi olan okullar }\end{array}$ & $\begin{array}{c}\text { Öğrenci } \\
\text { başına alan }\end{array}$ & $\begin{array}{c}\mathbf{4 0 0} \mathbf{~ m}^{2} \text { altında } \\
\text { bahçesi olan okullar }\end{array}$ & $\begin{array}{c}\text { Öğrenci } \\
\text { başına alan }\end{array}$ \\
\hline 17 okul $(\% 5,8)$ & $3,8 \mathrm{~m}^{2}$ & 3 okul $(\% 2,5)$ & $3,2 \mathrm{~m}^{2}$ \\
\hline
\end{tabular}

Okulda güvenliğin sağlanmasında da en önemli ve ilk düşünülmesi gereken, okulun çevirme duvarıdır. Kuşatma elemanı olarak taş, tuğla, briket ve tel örgü kullanılabilir. Bahçenin büyüklüğüne göre, 3 - 8 metre arasında oluşturulacak yeşil kuşağın üst kısmında uzun gövdeli, büyük taçlı ve geniş yapraklı ağaçlar; alt kısmında ise örtü çalıları, süs ağaç ve bitkilerinin bulunmalıdır (MEB, 1992). Okulların güvenliğinin sağlanması yollarından biri olan çevre duvarı, ilköğretim okullarının sadece bir köy okulunda bulunmazken; bulunanlarda kuşatma duvarı farklı şekillerde düzenlenmiştir.

Her iki çalışmada da (Tablo 7) okulların en fazla betonarme (2003 y1lı \% 36,3 ve 2018 yılı \% 47,1) duvara sahip oldukları belirlenmiştir. Okulların kuşatma duvarı düzenlemeleri geçmişteki (2003) düzenlemelerle benzerlik göstermektedir.

Son çalışmada (2018) demir parmaklıkların kuşatmada kullanıldığı okul sayısı 22 (\% 18,5) olarak ortaya çıkarken, 2003 yılı çalışmasına göre yüzde 2'lik bir azalma olmuştur. Bunların yaklaşık dörtte biri ( 5 okul) sadece demir parmaklık iken; diğerleri, bir metreye kadar yüksekliklerde, duvar üzerine döşenmiş demir parmaklıklar şeklindedir. Kuşatma duvarı 
bulunmakla birlikte, okulların 11 (\% 9,2)'sinde duvar iç kısımlarına yüksek ağaçlar; yüzde 2,4’ünde ise süs bitkileri niteliğindeki bodur ağaçlar dikilmiştir.

Tablo 7. İlköğretim Okullarının Çevre Duvarı Özellikleri

\begin{tabular}{lrrrr}
\hline & \multicolumn{2}{c}{$\mathbf{2 0 0 3}$ Yllı } & \multicolumn{2}{c}{$\mathbf{2 0 1 8}$ Yllı } \\
\cline { 2 - 5 } Özellikler & $\mathbf{n}$ & $\mathbf{\%}$ & $\mathbf{n}$ & $\mathbf{\%}$ \\
\hline Betonarme duvardır. & 106 & 36,3 & 56 & 47,1 \\
Yığma taş duvardır. & 90 & 30,8 & 24 & 20,2 \\
Demir parmaklıklarla çevrilidir. & 60 & 20,5 & 22 & 18,5 \\
Tel örgü ile çevrilidir. & 47 & 16,1 & 20 & 16,8 \\
Briket duvar vardır. & 41 & 14,0 & 19 & 16,0 \\
Çevre duvarı yoktur. & 27 & 9,2 & 1 & 0,8 \\
Yüksek ağaçlarla çevrilidir. & 25 & 8,6 & 11 & 9,2 \\
Harçsız taş duvar vardır. & 17 & 5,8 & - & - \\
Bodur ağaçlarla çevrilidir. & 7 & 2,4 & 3 & 2,5 \\
Duvar üzeri cam kırıkları ile döşenmiştir. & 1 & 0,3 & - & - \\
\hline
\end{tabular}

Yine son çalışmada harç kullanılmadan, taşların üst üste konulması ile örülmüş duvarlı okul bulunmamaktadır. Tel örgü ile çevrildiği ifade edilen okulların $10(\% 8,4)$ 'unda, tel örgünün mevcut duvarlar üzerine yükseltme ve geçişleri engellemek düşüncesiyle çekildiği ve dikenli tel oldukları anlaşılmaktadır.

\subsection{Okul Bahçelerinin Eğitim ve Eğitime Yardımcı Ortamlarına İliş̧kin Bulgular}

Çağdaş okul, sadece ders verilen ve ders alınan bir yer değil, ders dışı eğitimin, yetişkinler eğitiminin, kültürel etkinliklerin yer aldığı bir merkezdir. Okullar yapılırken bu amaçlar gözönünde bulundurulmalı, bu amaca hizmet edebilecek esnek, kullanışlı, ekonomik, öğrenci sağlığını geliştirici ve öğrenmeyi kolaylaştırıcı binalar yapımı benimsenmelidir (Alıcıgüzel, 1979, s. 63). Eğitim yeri denildiğinde, yalnız bu amaçla yapılmış binalardan öte, uygulama bahçesini, oyun alanını, bir işyerini, gözlem yapılan bir dereyi, tepeyi, bir eski kaleyi ve benzerlerini de kapsadığını söylemek olanaklıdır (Başaran, 1983, s. 243) Bu anlamda, okulları sadece derslikleriyle değil, bahçeleri ile de eğitsel etkinliklerin gerçekleştirilebileceği ortamlar olarak ele almak gerekmektedir (Kayhan ve Eroğlu, 1997). Ancak, Türkiye'deki ilköğretim okul bahçeleri, eğitim öğretim etkinliklerinin zenginleştirilmesi amaciyla kullanılabilecek eğitsel ve eğitime yardımcı olacak yerler bakımından da oldukça yoksun görünmektedirler. İlköğretim okullarının bir bölümü, bahçelerinde eğitsel ya da eğitime yardımcı alanların hiçbirine sahip bulunmazlarken, bazıları da bu olanakların birden fazlasına sahip bulunmaktadırlar.

Tablo 8'e bakıldığında, 2003 yılı ve son çalışma verileri okullarda bulunması zorunlu eğitsel ortamlardan olan Atatürk büstü ve köşesi tüm okullarda bulunmaktadır. İlköğretim okullarının bahçelerinde eğitsel ya da eğitime yardımcı alan olarak en fazla basketbol alanları bulunmakta $(\% 57,9)$ ve bunu 31,1 yüzdeyle futbol alanları izlemektedir. Bunları, okullarının sadece beşte birden biraz fazlasında (\% 21,0) bulunan voleybol alanları, yüzde 16,0 ile araç park yerleri, yüzde 14,3 ile uygulama bahçesi alanları izlemektedir.

İlköğretim okullarının ancak yüzde 5 'inde dinlenme alanı olarak düşünülecek kamelya bulunmaktadır. 11 okulda $(\% 9,2)$ trafik köşesi, birer okulda $(\% 0,8)$ kümes, meteoroloji köşesi ve tenis oynanabilecek alan bulunmaktadır. 2003 yılında yapılan araştırmada, bir okulda (\% $0,3)$ arılık türünde ortamın varlığı saptanmışken son çalışmada bu tür bir düzenlemeye rastlanmamıştır. Bu araştırmada bulunmayan geleneksel oyun alanları ve satranç köşeleri, son yapılan araştırmanın bulguları arasında yer almıştır. Son yıllarda okullarda geleneksel oyun alanları, satranç köşeleri, oyun parkı araçları köşesi gibi alanların yaygınlaştırılmasına yönelik 
çalışmalar Milli Eğitim Bakanlığı ve Gençlik ve Spor Bakanlığı tarafindan da destek görmektedir. 23 (\% 19,3) ilköğretim okulunda geleneksel oyun alanları bulunurken $11(\% 9,2)$ okulda da satranç köşeleri ile ilgili düzenlemeler bulunmuştur.

Tablo 8. İlköğretim okulları bahçesindeki eğitim ve eğitime yardımcı ortamlar

\begin{tabular}{lrrrr}
\hline & \multicolumn{2}{c}{$\mathbf{2 0 0 3}$ Yllı } & $\mathbf{2 0 1 8}$ Yılı & \\
\cline { 2 - 6 } & n & \% & n & \% \\
\hline Atatürk büstü ve köşesi & 292 & 100,0 & 119 & 100,0 \\
Voleybol alanı & 142 & 48,6 & 25 & 21,0 \\
Basketbol alanı & 139 & 47,6 & 69 & 57,9 \\
Uygulama bahçesi & 86 & 29,4 & 17 & 14,3 \\
Kum havuzu & 59 & 20,2 & 8 & 6,7 \\
Futbol alanı & 53 & 18,2 & 37 & 31,1 \\
Araç park yeri & 39 & 13,4 & 19 & 16,0 \\
Kamelya & 11 & 3,8 & 6 & 5,0 \\
Trafik köşesi & 7 & 2,4 & 11 & 9,2 \\
Kümes & 4 & 1,4 & 1 & 0,8 \\
Meteoroloji köşesi & 3 & 1,0 & 1 & 0,8 \\
Tenis kortu & 3 & 1,0 & 1 & 0,8 \\
Arılık & 1 & 0,3 & - & - \\
Geleneksel oyun alanı & - & - & 23 & 19,3 \\
\hline
\end{tabular}

İlköğretim okullarının tören, oyun ve dinlenme gibi eğitime yardımcı ortam olanaklarına ilişkin bulgular Tablo 9'de verilmiştir.

Tablo 9. İlköğretim okullarının tören, oyun ve dinlenme ortamları

\begin{tabular}{|c|c|c|c|c|c|c|c|c|}
\hline & \multicolumn{4}{|c|}{2003 Yilı } & \multicolumn{4}{|c|}{2018 Yllı } \\
\hline & \multicolumn{2}{|c|}{$\begin{array}{c}\text { Tören } \\
\text { Alanları }\end{array}$} & \multicolumn{2}{|c|}{$\begin{array}{c}\text { Oyun ve } \\
\text { Dinlenme } \\
\text { Ortamları }\end{array}$} & \multicolumn{2}{|c|}{$\begin{array}{c}\text { Tören } \\
\text { Alanları }\end{array}$} & \multicolumn{2}{|c|}{$\begin{array}{c}\text { Oyun ve } \\
\text { Dinlenme } \\
\text { Ortamları }\end{array}$} \\
\hline & $\mathrm{n}$ & $\%$ & $\mathrm{n}$ & $\%$ & $\mathrm{n}$ & $\%$ & $\mathrm{n}$ & $\%$ \\
\hline Yok & 52 & 17,8 & 55 & 18,8 & 3 & 2,5 & 3 & 2,5 \\
\hline Var & 234 & 80,1 & 230 & 78,8 & 116 & 97,5 & 116 & 97,5 \\
\hline Asfalt & 74 & 31,6 & 58 & 31,6 & 47 & 40,5 & 42 & 36,2 \\
\hline Beton & 66 & 28,2 & 30 & 28,2 & 42 & 36,2 & 28 & 24,1 \\
\hline Toprak & 50 & 21,4 & 92 & 21,4 & 18 & 15,5 & 35 & 30,2 \\
\hline Sikıştırılmış çakıl & 20 & 8,5 & 16 & 8,5 & 3 & 2,6 & 3 & 2,6 \\
\hline Parke taş & 12 & 5,1 & 8 & 5,1 & 5 & 4,3 & 3 & 2,6 \\
\hline Çim & - & - & - & - & - & - & 5 & 4,3 \\
\hline Başka & 12 & 5,1 & 26 & 5,1 & 1 & 0,9 & - & - \\
\hline Yanit vermeyenler & 6 & 2,1 & 7 & 2,4 & - & - & - & - \\
\hline TOPLAM & 292 & 100,0 & 292 & 100,0 & 119 & 100,0 & 119 & 100,0 \\
\hline
\end{tabular}

Buna göre, okulların sadece 3'ünde amacına uygun olarak düzenlenmiş bir tören alanı bulunmazken, 116 (\% 97,5)'sında tören alanının bulunduğu saptanmıştır. Tören alanları olan ilköğretim okullarının tören alanlarının durumuna bakıldığında, yaklaşık üçte birden fazlasının (\% 40,5) asfaltla kaplı bir tören alanına; yüzde 36,2'sinin beton, yüzde 15,5'inin toprak, yüzde 
2,6'sının sıkıştırılmış çakıl ve yine yüzde 2,6'sının ise parke taşla kaplı alanlara sahip oldukları bulunmuştur.

Tablo 9'da, ilköğretim okullarının oyun ve dinlenme alanları ile ilgili durumları da ortaya konulmaktadır. Tablodaki verilere göre, ilköğretim okullarının yüzde 97,5 'i oyun ve dinlenme amaçlı alanlara sahipken, yüzde 2,5 'i bu olanaktan yoksun bulunmaktadır. Oyun ve dinlenme alanlarının zemin özellikleri ile ilgili olanaklar incelendiğinde, okulların 35 (\% 30,2)'inde zeminin toprak, 42 (\% 35,2)'sinde asfalt, 28 (\% 24,1)'inde beton, 3'er okulda (\% $2,6)$ da sıkıştırılmış çakııl ve parke taş olarak düzenleme yapıldığı görülmektedir. Beş $(\% 4,3)$ okulda da oyun ve dinlenme alanlarında çim düzenlemelerin yapıldığı bulunmuştur.

Tablo 10'da da görüleceği üzere, 27 (\% 22,7) ilköğretim okulu yöneticisi okullarında özel çim alanlarının bulunduğunu, 92 (\% 77,3) yönetici ise, böyle bir alana sahip olmadıklarını ifade etmişlerdir. Özel çim alanlarına sahip bulunduklarını ifade eden okul yöneticilerin de yüzde 77,8 (21 okul)'i düzenlenmiş bulunan çim alanlara basılmasını yasakladıklarını, yüzde 22,2 (6 okul)'si ise böyle bir yasaklamaya gitmediklerini belirtmişlerdir.

Tablo 10. İlköğretim okullarının özel çim alanları bakımından durumu

\begin{tabular}{crrrr}
\hline \multirow{2}{*}{ Özel Çim Alanları } & \multicolumn{2}{c}{$\mathbf{2 0 0 3}$ Yılı } & $\mathbf{2 0 1 8}$ Yılı \\
\cline { 2 - 5 } & $\mathbf{n}$ & $\mathbf{\%}$ & $\mathbf{n}$ & $\mathbf{\%}$ \\
\hline Yok & 215 & 73,6 & 92 & 77,3 \\
Var & 70 & 24,0 & 27 & 22,7 \\
Çimlere basmak yasaklanmiştır. & 48 & 68,6 & 21 & 77,8 \\
Çimlere basmak yasaklanmamıştır. & 22 & 31,4 & 6 & 22,2 \\
Yanıt vermeyenler & 7 & 2,4 & - & - \\
TOPLAM & 292 & 100,0 & 119 & 100,0 \\
\hline
\end{tabular}

İlköğretim okulları, çim alan olanaklarına göre, okul bahçesinde bulunan ağaç olanakları bakımından daha şanslı görünmektedirler. Bahçelerinde çim alanları bulunanlar yaklaşık dörtte bir ile sınırlı kalırlarken, ağaç toplulukları bakımından tersi bir görünüm (\% 54,6 ağaç topluluğu) ortaya çıkmaktadır.

Tablo 11. İlköğretim okullarının ağaç toplulukları bakımından durumu

\begin{tabular}{|c|c|c|c|c|}
\hline \multirow[b]{2}{*}{ Ağaç Toplulukları } & \multicolumn{2}{|c|}{2003 Yilı } & \multicolumn{2}{|c|}{2018 Yılı } \\
\hline & n & $\%$ & $\mathbf{n}$ & $\%$ \\
\hline Yok & 114 & 39,0 & 54 & 45,4 \\
\hline Var & 174 & 59,6 & 65 & 54,6 \\
\hline 25 ve daha az ă̆aç & 102 & 34,9 & 43 & 36,1 \\
\hline $26-50$ ă̆aç & 25 & 8,6 & 11 & 9,2 \\
\hline $51-100$ ă̆aç & 18 & 6,2 & 7 & 5,9 \\
\hline $101-200$ ağaç & 15 & 5,1 & 3 & 2,5 \\
\hline 201 - ve fazla ağaç & 14 & 4,8 & 1 & 0,8 \\
\hline Yanit vermeyenler & 4 & 1,4 & - & - \\
\hline TOPLAM & 292 & 100,0 & 119 & 100,0 \\
\hline
\end{tabular}

Okul bahçelerinde bulunan ağaç topluluklarının sayısal dağılımına bakıldığında, 2003 yılına göre son çalışmanın bulguları ağaçlık okullardaki alanlarda azalma olduğunu göstermektedir. 2003 yılında ağaçlık alan olanağa sahip bulunan okullar yüzde 58,6 iken son çalışmada yüzde beşlik bir azalma göstermiştir. Diğer taraftan, yapılan son çalışmanın verilerine göre 26-50 arasında ağaca sahip okullarda küçük bir artış görülürken, 51 ve üzerinde ağaca sahip okullarla, 25 ve altında ağaca sahip okullarda ağaç sayılarında azalma saptanmıştır. 
Tablo 11'de yer alan verilere göre, 2003 yılında bahçelerinde ağaçlık alanlara sahip okullarda, okul başına ortalama 42,8 ağaç düşerken; son çalışmada ortalama 34,1 ağaç düştüğü bulunmuştur. Okullar genel olarak ele alındığında, okul başına düşen ortalama ağaç sayısı, 2003 yılında 25,5 ve gelinen noktada 18,6 ağaç ile çok düşük kalmaktadır. Öğrenci başına bir ağaç düşmesi bir yana, sınıf başına düşen ağaç sayısı bile, her iki çalışmada, ancak iki (2) ağacın altındadır.

\section{TARTIŞMA, SONUÇLAR ve ÖNERILER}

Çalışma bulgularına dayalı olarak yapılan tartışmalar aşağıda verilmiştir.

\subsection{Tartışma}

Özellikle, kentlerde bulunan ilköğretim okulları, mekânsal ve arazi bakımlarından büyüme ve gelişme olmaksızın, her geçen gün, kuruluşundaki planlanan öğrenci sayılarından daha fazlasını bünyelerine katmakta ve bu durum artarak devam etmektedir. Kırsal alan yerleşim birimlerinde ise tersine bir durum yaşanmakta; hatta taşımalı eğitim ve yatılılık uygulamalarıyla bazı okullar da kapanmaktadırlar. Şehir okullarında kapasitelerinin üzerinde başvuruya yanıt verebilmek için, bahçe alanları küçültülmüş; sevimsiz, estetikten ve ana bina ile bütünlükten uzak ek binalarla olumsuz bir bahçe ortamı ortaya çıkmıştır. Okul bahçeleri, Milli Eğitim Bakanlığı (2012)'nın “Okul bahçeleri düzenleme ilkeleri, ihtiyaç programları açıklamaları ve örnek projeler" adlı çalışmasındaki planlamalardan uzaktır.

\subsubsection{Okul Yerleri ve Uygunluğuna İlişkin Tartışma}

Okulların kurulacağı yerlerin seçiminde titizlikle hareket edilmesi bir zorunluluktur. Okulların eğitsel çalışmalarına katkı sağlayacak, uygulamalara firsatlar sunacak bir çevrede kurulması, olumsuz etkileyecek ortamlardan uzak olması gerekir. Okulların ve içindeki öğrencilerin güvenliğinin sadece kuşatma alanları ile sağlanması düşünülmemeli; daha okul yeri seçilirken çevresinin trafik, gelişme vb. özellikleri göz önünde bulundurularak planlamalar yapılmalıdır. 2003 yılına kıyasla 15 yıl sonrasına gelindiğinde, okulların yakınındaki taşıt durakları, kahvehane, meyhane vb. yerlerde azalmalar gözlenmiştir. Buna karşıllk özellikle kentlerdeki hızlı ve kontrolsüz gelişmeler sonucu okullar adeta konutlar arasına sıkışmış durumdadır. 15 yıllık süre içinde, açılan yeni okullar da durumda fazla bir değişkilik oluşturmadığı gibi konutlar arasına sıkışan okul sayısında artış meydana gelmiştir. Bu olumsuzluklrın yaşanmaması için yerleşim birimleri ve okul yerlerinin planlanmasında gerekli özen gösterilmelidir. Okul yerlerinin uygun özellikte tutulabilmesinin yollarından biri de yerleşke düzeni olabilir.

Temel eğitim hizmeti veren okulların öğrencilerin kolay ulaşabilecekleri mesafede olması önemlidir. 2012-2013 öğretim yılından itibaren ğrencilerin, ulusal adres veri tabanında belirtilen ikametgâhlarına en yakın ilköğretim okuluna kaydedilmeleri esas alınmıştır. 2003 yılına kıyasla bu düzenlemenin, okula öğrenci alınacak mesafeyi azaltmasına karşın etkili bir çözüm olmadığı görülmektedir. Öğrenciler hala yaş ve gelişim özelliklerine uygun olmayan bir mesafeden okullara gelmektedirler ve bu arzulanan bir durum değildir. Bunda, velilerin daha nitelikli gördükleri okulları seçme düşüncelerinin etkili olduğu söylenebilir. Velilerin ikamet ettikleri yerleşim birimi yakınındaki okulları tercih etmelerine yönelik yasal düzenlemeler değişik yollarla aşılabilmektedir. Dolayısıyla bazı okullarda öğrenci yığılmaları bazılarında ise kapasitelerinin altında öğrenciye hizmet verme durumları yaşanmakta ve okulların etkili kullanımı gerçekleşememektedir. Bu olumsuz durumun aşılmasında yasal düzenlemeler kadar okulların niteliklerinin yükseltilmesi ve her birinin tercih edilen okul niteliğine kavuşturulmasına yönelik çalışılmalar yapılması gerekir.

Okulun, biri ön ve diğeri arkada en az iki giriş kapısının bulunması gerekir. Ön kapının araç girişine de olanak verecek, ancak sadece öğrenci, işgörenler ve ziyaretçilerin girecekleri; arka kapı ise, araçların sürekli girişine de uygun olacak şekilde düzenlenmelidir (Wallace, 
1992). Araç girişinin arka kapıdan yapılması özellikle öğrenci güvenliği açısından önemlidir. Bahçe içinde araçların kullanacakları yollar da, öğrencilerin yoğun bulunduğu oyun ve dinlenme alanlarına uzak olmalıdır. Okul ana giriş kapılarının ana caddelere ve işlek sokaklara açılmaması ya da doğrudan açılmaması gerekir. Gelinen noktada, ana caddeye açılan ilköğretim okulların sayısında azalma olmakla birlikte, mevcut durumdaki kaza vb. olumsuzlukların yaşanmaya devam etmesi, bu yönde olumlu bir gelişmeyi sağlayacak düzenlemelere ihtiyacın devam ettiğini göstermektedir.

Alanyazında ilköğretim okulları bahçe alan büyüklüğünün öğrenci başına en azbeş metrekare ve genelde $400 \mathrm{~m}^{2}$ olması idealize edilmektedir. 2003 yılındaki çalışmada görülen bu yöndeki standartlara uygun olmayan durum varlığını sürdürmektedir. Hatta öğrenci başına düşen alan, daha da azalmıştır.

Okulda sağlanmasında da en önemli ve ilk düşünülmesi gereken, okulun çevirme duvarıdır. Kuşatma elemanı olarak taş, tuğla, briket ve tel örgü kullanılabilir. Bahçenin büyüklügüne göre, 3 - 8 metre arasında oluşturulacak yeşil kuşağın üst kısmında uzun gövdeli, büyük taçlı ve geniş yapraklı ağaçlar; alt kısmında ise örtü çalıları, süs ağaç ve bitkilerinin bulunmalıdır (MEB, 1992). Bulgulara göre, okulların güvenlik ve düzeni sağlamalarında önemli işlevi olan çevre (kuşatma) duvarları estetik ve eğitsel önem taşımaktan uzaktır. Geçen 15 yıllık süre içinde, kuşatma duvarı düzenlemelerinde tehlike yaratabilecek harçsız taş duvar, duvar üzeri cam kırıkları bulunan okul kalmamış, çevre duvarı olmayan okul çok azalmış olmakla birlikte yetersizlikler devam etmektedir. Kuşatma duvarı bulunan okulların ortaya koyduğu; dışarısıyla bağlantısı kesilmiş, çevrenin merkezinde fakat çevre ile iletişimden kopuk, öğrencide tutsak edilme duygusunu uyandıracak yüksek duvarlı, tel örgülü, demir parmaklıklarla daha da yükseltilmiş olumsuz bir görüntüdür. Çağdaş örgüt ve eğitim yaklaşımları, çevre ile uyumlu, etkinlikleriyle çevresini de geliştiren anlayışları öne çıkarmaktadır. Güvenliği de sağlayan, ancak estetik değerleri ve örnek uygulamaları çevresine sunan bir okul örgütü çevresi tarafından daha kolay benimsenip sahiplenilecektir. Fakat ilköğretim okullarının çoğu, kuşatma duvarları ve bahçe düzenlemeleriyle çevresine örnek olmaktan uzak bir görüntü sergilemeye devam etmektedirler.

Güvenlik, fiziksel gelişmelerini istenen düzeyde tamamlamış, özdenetimi yeterince gelişmemiş ilköğretim çağı çocukları için büyük önem taşır. Çevresi, yapıları ve donanımlarıyla güvenli ortamlar olması gereken okul ortamlarında halen önemli güvenlik sorunlarının bulunduğu söylenebilir. Günümüzde bile okul bahçelerinin birçoğunda oyun alanlarının bile asfalt ya da beton kaplı olması, öğrenci başına düşen alanların yetersizlikleri, güvenlik sorununun varlığını ortaya koymaktadır. Ayrıca doğrudan ana caddelere açılan kapıları bulunan okulların da güvenlik sorunu yaşadıkları söylenebilir.

\subsubsection{Okul Bahçeleri Eğitim ve Yardımcı Ortamlarına İlişkin Tartışma}

Çağdaş okul, sadece ders verilen ve ders alınan bir yer değil, ders dışı eğitimin, yetişkinler eğitiminin, kültürel etkinliklerin yer aldığı bir merkezdir. Okullar yapılırken bu amaçlar gözönünde oulundurulmalı, bu amaca hizmet edebilecek esnek, kullanışlı, ekonomik, öğrenci sağlığını geliştirici ve öğrenmeyi kolaylaştırıcı binalar yapımı benimsenmelidir (Alıcıgüzel, 1979, s. 63). Eğitim yeri denildiğinde, yalnız bu amaçla yapılmış binalardan öte, uygulama bahçesini, oyun alanını, bir işyerini, gözlem yapılan bir dereyi, tepeyi, bir eski kaleyi ve benzerlerini de kapsadığını söylemek olanaklıdır (Başaran, 1983: 243) Bu anlamda, okulları sadece derslikleriyle değil, bahçeleri ile de eğitsel etkinliklerin gerçekleştirilebileceği ortamlar olarak ele almak gerekmektedir (Kayhan ve Eroğlu, 1997).

İlköğretim okullarının bahçe alanlarında geçen 15 yılda öğrenci sayısına göre azalma görülmesine karşılık, okul bahçe düzenlemelerinde duvar boyamaları ile geleneksel oyun alanları ve satranç köşesi gibi düzenlemeler bir farklılaşma olarak öne çıkmaktadır. Oysa 
okulların sadece derslikleri değil, her köşesi eğitsel bir alan gibi düşünülmeli ve bu yönde düzenlemelere gidilmelidir. Okul bahçeleri, sınıf içi etkinliklere göre, öğrenmenin yaşantılar yoluyla gerçekleşmesine yönelik firsatların daha fazlasını sunabilir. Okul bahçelerine, okulun hedefleri doğrultusunda, eğitsel ve yardımcı ortam düzenlemeleri yapıldığı takdirde, önemli kazanımlar elde edilebilir. Ancak, okulların yarısından fazlasında bu türden düzenlemeler bulunmamaktadır. Yasal metinlerle de istenmiş olmasına karşın; uygulama bahçesi, kümes, meteoroloji köşesi, arılık gibi alanlar ve ortamlar, okul yönetimlerinin düşüncelerinden büyük oranda çıkmış, varolan olanaklar da kullanımdan çıkarılmaya başlanmıştır.

Gittikçe daralan oyun alanları yanında; daha temiz ve çamurdan uzak olur düşüncesiyle, okul bahçelerinin asfalt ya da betonla kaplanmaya başlanması uygulamaları çoğalmıştır. Bu yolla öğrenciler rahat ve korkusuzca hareket edebilecekleri alanlardan yoksun kalmış; diğer taraftan çamur sorunu bitmiş ama yağmur sonrası suların boşaltılamamasından dolayı, okul bahçelerinde gölcükler oluşmaya başlamıştır. Görüşmeler sırasında öğretmenlerden biri; okullarının bahçesinde bulunan tek ağacın yanına yenilerinin ekilmesi, bahçenin ağaçlandırılması amacıyla, öğrencileriyle birlikte ağaç dikme kararı aldıklarını; asfaltlanan bahçelerinin kuşatma duvarı kenarlarında, asfaltı kırarak açtıkları çukurlara fidan diktiklerini; ancak, toprağın yeterince havalandırılamadığı ve güneş enerjisini alamadığı için fidanların ya tutmadığını ya da kısa sürede kuruduklarını ifade etmiştir.

Öğrenci başına en azından bir ağaç düşmesi gereken okulların sahip oldukları ağaç sayısı, bu rakamın oldukça gerisinde kalmıştır. Çimlendirilmiş yeşil alanların bulunduğu okul oranı da yüzde 24,0'lerde kalmaktadır. Üstelik okul bahçelerindeki çimlerin üçte ikisi süs çimi özelliğindedir ve üzerlerine basılması yasaklanmıştır. Üzerinde oturulacak, dinlenilecek özellikte olması gereken çim alanları çok az okulda bulunmaktadır. Genel olarak bakıldığında, ilköğretim okullarının yeşil alanlar bakımından oldukça sınırı olduğu söylenebilir. Şehirlerdeki okullar bir yana, verimli toprakların, yeşil alanların ve ağaçların bulunduğu birçok köyde bulunan ilköğretim okulu da yeşil alanlardan ve ağaçlandırmadan yoksun bir görünüm ortaya koymaktadır. Oysa bölgenin egemen olan rüzgâr ve çevresel gürültünün geldiği yönlere ağaçlandırmaların yapılması; hem rüzgârı, hem de gürültüyü engellemede yardımcı olabilecektir.

\subsection{Sonuçlar}

Çalışmanın bulguları ve yapılan tartışmalara bağlı olarak şu sonuçlar çıkarılmıştır:

1. Okul yeri ve konumu bakımından okullar, 15 yıl öncesinde olduğu gibi, yetersiz bir durum sergilemektedir. Geçmişte uygun bir yer olarak inşa edilen okulların büyük bölümü, hızlı kentleşme etkisiyle, binalar arasına sıkışmış ya da yeni binalar uygun olmayan yerlere yapılmak zorunda kalmıştır. Bu durum, eğitimi olumsuz etkileyecek ses ve görüntü kirliliği yanında, tehlikelere açık riskli durumlara zemin hazırlayabilmektedir. Öğrencilerin kısmen daha kısa bir mesafeden okula geliyor olmaları olumlu bir gelişmedir.

2. Eğitim etkinliklerine önemli katkısı olan okul bahçe düzenleri bakımından okulların yeterliliğinde kayda değer bir gelişme gözlenmemiştir. Öğrenci başına düşmesi gereken alanlar da standartların altındadır.

3. Her iki çalışmada da okulların birkaçı dışında, eğitim kurumlarına uygun düşecek ve çevresine örnek olacak kuşatma duvarına sahip okul bulunmamaktadır. Bazı okulların kuşatma alanları ise, çevresine olumsuz örnek olacak özelliktedir. Okul bina ya da bahçe kapılarının, üçte birden fazlasının, işlek olan ana caddelere açılıyor olması bir 
olumsuzluk olduğu gibi, kazalara da ortam hazırlayabilecek bir durum olarak ortaya çıkmaktadır.

4. Okul bahçelerinde, eğitsel ve eğitime yardımcı olan olanaklarında bir çeşitlilik gözlenmekle birlikte, yetersiz görünümden kurtulamamıştır. Yeni açılan okullarda da okul bahçelerine yönelik düzenlemelerin göz ardı edildiği saptanmıştır

5. Çevre düzenlemeleriyle, yer aldığı çevreye de örnek olması beklenen okulların bahçeleri, çim ve ağaçlandırma gibi yeşil alan olanaklarından da yoksundur. Hatta geçen 15 yılda daha da azalma göstermiştir. Bu olanağa sahip bulunan okulların da çok azında çimlere basmak yasaklanmamıştır ve oturma, dinlenme alanı olarak kullanılmasına izin verilmektedir. Yasaklama getirilen okullardaki yeşil alan çimleri ise, küçük bir alanda bulunan ve genel olarak süs çimi ya da çiçeklik tarhı türündedir.

6. 2003 yılına kıyasla, okulların yerleşim birimlerine sıkışmışlığın devam ettiği; okul sayılarında görece artışa rağmen öğrenci başına düşen alanlarda, ağaçlandırma, çim vb. yeşil alanlarda azalma; eğitsel ve eğitime yardımcı alanlarda kısmi artışların olduğu sonuçlarına ulaşılmıştır.

\section{3. Öneriler}

Uygulayıcılara ve araştırmacılara yönelik geliştirilen öneriler şunlardır:

1. Okul bahçelerinin çevre duvarları çevresi ile iletişimi engellemeyecek şekilde ve en fazla bir metre yükseklikte yapılmalıdır. Duvarın beton ya da harçlı taş duvar şeklinde yapılması yerine, arasına tel örgü çekilmiş çit bitkileri ile oluşturulması; beton ya da taş duvar yapılması halinde, iç kısımların bitki ve ağaç dikilmesi, okula görünüm zenginliği kazandıracaktır.

2. Okul bahçelerinde açık spor alanları, dinlenme ve tören yerleri, uygulama bahçesi, hayvanat bahçesi, meteoroloji köşesi, kum havuzu, eğitsel etkinlikler köşesi, satranç köşesi, çocuk oyunları alanı, açık hava dersliği, yürüyüş ve bisiklet parkuru vb. mekânlar oluşturulmalı ya da öğrencilerin etkili kullanabilecekleri miktarda arttırilmalidir.

3. Yeşil alanlar okulların vazgeçilmez olanakları olarak düşünülmeli; bahçede, en azından her öğrenciye bir ağaç düşmeli; düzenlenecek çim alanlar görsellik yanında, dinlenme yerleri olarak da düşünülmelidir. Ayrıca, ağaçların seçiminde ve dikilmesinde, gürültü, rüzgâr önleyici ve gölge yapıcı özellikleri dikkate alınmalıdır.

4. Okul bahçesindeki alanların asfalt, beton ile kaplanmasından vazgeçilmeli; olabildiğince çimlendirmeye gidilmeli ve bağlantı yolları gibi yerlere de arnavut kaldırımı veya parke taş döşenmelidir. Olanaklar elvermiyorsa, en azından oyun alanları kumlandırılmalı veya toprak olarak kalmalıdır.

5. Okul planlama ve düzenlemeleri, öğrenme ve öğretme etkinliklerine zenginlik katma yanında, çevrenin eğitimi ve geliştirilmesi için bir fırsat olarak düşünülmeli; okul bahçe ve bina tasarımında eğitim bilimleri uzmanları, peyzaj mimarları görev almalidirlar.

6. 2020 yılında yaşanan ve gelecek yıllarda da benzer süreçlerin ortaya çıkabileceği öngörüleri dikkate alınarak; bu durumun okul ortamlarına etkilerine yönelik araştırmalar yapılabilir, okul eğitim ortamları ile ilgili yeni tasarımlar geliştirilebilir.

7. İlkokul ve ortaokullar yanında, okulöncesi ve ortaöğretim kurumlarında benzer konuda çalışmalar yapacak araştırmacılar, okul bahçelerinin; a) donanımları, b) 
ergonomik özellikleri c) öğrenci davranışlarına etkileri konularında çalışmalar yapabilirler. 


\section{KAYNAKLAR}

AKGÜL GÖK, Z., (2012), İlköğretim Okul Bahçelerinin Öğrencilerin Tercihleri ve Doğa Bilinci Gelişimini Destekleyici Yaklaşımlar Doğrultusunda Tasarımı: Isparta Kenti Örneği. Yüksek Lisans Tezi, Süleyman Demirel Üniversitesi, Fen Bilimleri Enstitüsü.

AKSU, Ö. V., DEMIREL, Ö. ve BEKTAŞ, N., (2011(, Trabzon Kenti İlköğretim Okul Bahçelerinde Donatı Elemanları Üzerine Bir Araştırma, İnönü Üniversitesi Sanat ve Tasarım Dergisi, 3, 243-254. Malatya: İnönü Üniversitesi.

ALGAN, A. ve USLU, C., (2009), İlköğretim Okul Bahçelerinin Tasarlanmasına Paydaş Katılımı: Adana Örneği, Akdeniz Üniversitesi Ziraat Fakültesi Dergisi, 22(2), 129-140.

ALICIGÜZEL, İ., (1979), İlk ve Orta Dereceli Okullarda Öğretim, 4. Basım, İstanbul: İnk1lâp ve Aka Kitapevleri.

ALKAN, C., 1979, Eğitim Ortamları, Ankara: Ankara Üniversitesi, Eğitim Bilimleri Fakültesi Yayınları No: 85.

------, C., 1983, "Eğitimde ergonomi”, Eğitim Bilimleri Fakültesi Dergisi, Ankara: Ankara Üniversitesi, Eğitim Bilimleri Fakültesi Yayını.

ALPARSLAN, İ., (1993). Okullarda Gözlem, Erzurum.

ALTUNIŞIK, R., COŞKUN, R., BAYRAKTAROĞLU, S. ve YILDIRIM, E., (2010), Sosyal Bilimlerde Araştırma Yöntemleri SPSS Uygulamalı, Sakarya: Sakarya Yayıncılık.

ASLAN, F., (2010), Okul Öncesi Eğitim Kurumlarında Dış Mekan Tasarımında Çocukların Beklentilerinin Belirlenmesi, Doktora Tezi, Ankara Üniversitesi, Fen Bilimleri Enstitüsü.

BAŞARAN, İ. E., (1982), Temel Eğitim ve Yönetimi, Ankara: Ankara Üniversitesi, Eğitim Bilimleri Fakültesi Yayını.

, İ. E., (1983), Eğitim Yönetimi, Ankara.

, İ. E., (1996), Yönetim, Ankara.

BAŞAR, M. A., (2000), İlköğretim Okullarının İşgören ve Fiziki Olanakları”, Pamukkale Üniversitesi Eğitim Fakültesi Dergisi Özel Sayı, Denizli: Pamukkale Üniversitesi, Eğitim Fakültesi Yayını, ss. 142-146.

------, (2003), İlköğretim Okullarının Olanakları, Yayınlanmamış Doktora Tezi, Ankara Üniversitesi, Eğitim Bilimleri Enstitüsü.

BAŞOĞLU, Z., (2007), İlköğretim Çağındaki Çocukların Yön Bulma Davranışlarının Biçimlenmesinde İç Mekan Renk Uygulamalarının Etkileri. Sanatta Yeterlik Tezi, Hacettepe Üniversitesi, Sosyal Bilimler Enstitüsü.

BLAIR, D., (2010), The Child in the Garden: An Evaluative Review of the Benefits of School Gardening, The Journal of Environmental Education, 40(2), ss. 15-38.

BÜYÜKÖZTÜRK, Ş., ÇAKMAK, E. K., AKGÜN, Ö. E., KARADENIZ, Ş. ve DEMIREL, F., (2012). Bilimsel Araştırma Yöntemleri. (Geliştirilmiş 13. Baskı). Pegem Akademi Yayıncılık, Ankara.

BURSALIOĞLU, Z., (2019), Okul Yönetiminde Yeni Yapı ve Davranış, 20. Baskı, Ankara: Pegem Yayını.

CAN, H., (1991), Organizasyon ve Yönetim, Ankara: Adım Yayıncılık. 
CHAU, T. N., 1989, Eğitim Planlamasının Demografik Yönleri, Çev.: Reşide Kabadayı, Ankara.

CRAMER, J. F. ve BROWNE, G. S., (1982), Çağdaş Eğitim Milli Eğitim Sistemleri Üzerine Bir İnceleme, (Çev. F. Oğuzkan) İstanbul: Milli Eğitim Basımevi.

ÇETINER, A., (1972), Şehircilik Çalışmalarında Donatım Ilkeleri. İstanbul: İTÜ Mimarlık Fakültesi.

DPT, (2001), İllerin ve Bölgelerin Sosyo-Ekonomik Gelişmişlik Sıralaması Araştırması. Yayın No: 2671, Ankara.

DYMENT, J. E., (2005), Green School Grounds as Sites for Outdoor Learning: Barriers and Opportunities, International Research in Geographical \& Environmental Education, 1, $14,28-45$.

ERELI, E., (2001), Türkiye'deki İlköğretim Okul Bahçelerinde Peyzaj Planlama ve Tasarım İlkelerinin Saptanması. Ankara Üniversitesi Fen Bilimleri Enstitüsü. Yüksek Lisans Tezi.

ERGEN, Y. B., (1986), Bina Bilgisi. İstanbul: Milli Eğitim Basımevi.

EVERGREEN, (2001), Bringing Nature to Our Cities, Toyota Canada Inc. and its Dealerships - Proudly Supporting Outdoor Classrooms in Canadian Schools.

GOLLWITZER, G. v.d., (1959), Okul Bahçeleri, Çev. N. Taner ve P. Taner, Ankara.

GÜLER Ç. ve ÇOBANOĞLU, Z., (1994), Çocuk ve Çevre. Ankara: Sağlık Projesi Genel Koordinatörlüğü.

HALlAK, J., (1976), La Mise En Place De Politiques Educatives: Role Et Methodologie De La Carte Scolaire. Paris: UNESCO, IIPE.

HESAPÇIOĞLU, M. ve MERIÇ, B., (1994), Okul Binalarının Tasarımı, Türkiye ve Istanbul Ilinde Eğitim Tesisleri-Nüfus Ilişkisi-Eğitim Planlaması ve Ekonuomisi Açısından Bir Ön Çözümleme, Eğitim Bilimleri Dergisi, Sayı: 6, İstanbul: M.Ü. Atatürk Eğitim Fakültesi Yayını.

IŞIL, B., (1991), Ergonomi. İzmit: Yıldız Üniversitesi Yayınları, No: 228.

KALKINMA BAKANLIĞI, (2013), İllerin ve Bölgelerin Sosyo-Ekonomik Gelişmişlik Sıralaması Araştırması (SEGE-2011). Ankara.

KANRA, G., (1991), Ergonominin Eğitimde Yeri, 1. Ergonomi Kongresine Sunulan Bildiri.

KARADAĞ, A. A., MUTLU, S. ve SAYIN, Ş., (2012), Okul Bahçelerinin Oyun Alanı Olarak Değeri: Düzce Kenti Örneği, Ormancılık Dergisi, 8(2), 45-56.

KARAKÜTÜK, K., (1994), Eğitim Planlamasında Öğretim Haritası Yönteminin Rolü, Önemi ve Türkiye'de Uygulama, Yayınlanmamış Doktora Tezi, Ankara: Ankara Üniversitesi, Sosyal Bilimler Enstitüsü.

KARASAR, N., (2012), Bilimsel Araştırma Yöntemi, 24. Basım, Nobel Yayın Dağıtım, İstanbul.

KARASOLAK, K., (2009), Mimari Özellikleri Farklı İlköğretim Okullarındaki Öğrenci ve Öğretmenlerin Okullarının Bina ve Bahçeleri Hakkındaki Görüşlerinin İncelenmesi, Yüksek Lisans Tezi, Çukurova Üniversitesi Sosyal Bilimler Enstitüsü. 
KARASOLAK, K. ve SARI, M., (2011), Mimari Özellikleri Farklı Okullardaki Öğrenci ve Öğretmenlerin Okullarının Binası Hakkındaki Görüşlerinin İncelenmesi, Çukurova Üniversitesi Eğitim Fakültesi Dergisi, 3(40), 132-154.

KARIP, E. vd., (2002), Sınıf Yönetimi, Ankara: PEGEM Yayınları.

KAYHAN, Ü. ve EROĞLU, G., (1997), Eğitim Ortamlarının Incelenmesi, (Ders Notu), Ankara.

KLEBERG, R. J., (1998), Über Die Qulietät Von Lernräumen”, Bildung Und Erziehung, 51 Jg. Heft 1/März, ss. 29-36.

KOCAOLUK, F., (1983), İlköğretimde Temel Mevzuat, 2. Bası, İstanbul: Kocaoluk Yayınevi.

KURT, M. ve GÜÇLÜ, F., (1997), İlk ve Ortaöğretimde Öğrencilerin Ergonomik Açıdan Okula Uyumları, Kalkınmada Anahtar Verimlilik, Cilt: 9, Sayı: 99, Ankara: MPM Yayını.

KUŞ, C., (2001), Ankara Kenti Yenimahalle İlçesi’nde Okul Bahçeleri Üzerine Bir Araştırma, Yüksek Lisans Tezix Ankara Üniversitesi Fen Bilimleri Enstitüsü.

KÜÇÜKAHMET, L. (1986), Okul Binalarının Eğitsel Kullanımı, Çağdaş Eğitim Dergisi, Cilt: 11, Sayı: 113, Ankara: Rehber Yayınevi.

LOPEZ, R., CAMPBELL, R. ve JENNING, J., (2008), The Boston Schoolyard Initiative: A Public-Private Partnership for Rebuilding Urban Play Spaces Journal of Health Politics, Policy and Law. Duke University.

MILLI EĞITIM BAKANLIĞI, (2011), Okullar Hayat Olsun Projesi Uygulama Protokolü, Ankara.

-------, (2016), Milli Eğitim Istatistikleri, Ankara.

------, (2012), 12 y1llık zorunlu eğitim. Sorular cevaplar, http://www.meb.gov.tr/duyurular/ duyurular 2012/ 12Yil_Soru_Cevaplar.pdf

------, (2011), Okullar Hayat Olsun Projesi Uygulama Protokolü, Ankara.

------, (2008), İlköğretim Kurumları Yönetmeliği, Resmi Gazete, Sayı: 21308, 7.8 (Değişik: 24.12.2008/27090 RG).

-------, (1986), İlköğretim Kurumlarının Açılması ve Kapatılması Hakkında Yönerge, Sayı: 14222, 12.6.1986.

-------, (1992), İlköğretim Kurumları Yönetmeliği, Resmi Gazete, Sayı: 21308, 7.8.

-------, (1985), Okul Yeri ve Seçimi, Tebliğler Dergisi, No: 2198, 4 Kasım.

NEFF, K., A. LAUWERYS, J. A., VARIŞ, F., (1979), Mukayeseli Eğitim, Ankara: Ankara Üniversitesi Eğitim Bilimleri Fakültesi Yayınları.

NEUFERT, E., (1977), Yapı Tasarımı Temel Bilgileri, Çev.: A. Erkan, Ankara: Güven Kitabevi.

-------, (1980), Architect's Data, New York.

ÖZDEMIR, A., (2011), Bir Okul Bahçesinin Değişimi: Bartın Akpınar İlköğretim Okulu Peyzaj Projesi, İnönü Üniversitesi Sanat ve Tasarım Dergisi, 1, 3, 267-278.

ÖZDEMIR, A. ve ÇORAKÇI, M., (2010), Ankara Okul Bahçelerinin Katılımcı Yöntemle Yenilenmesi, Milli Eğitim Dergisi, 186.

RAMSEY, M. ve RYDEEN, J. E., (1989), Fernbrook Elementary Schools Easy Style Makes It A Prototype For Growt”. American School Board Journal, 176(6), s.s. 36-37. 
SAĞLIK BAKANLIĞI, (1992), Birinci Ulusal Sağlık Kongresi, Çalışma Grupları Raporları, Ankara.

SAĞLIKOVA, Y. (1990), Orta Eğitim İçin Bir Kampus, Tasarım, Yı1: 1, Sayı: 4, İstanbul.

SAKA, E., (2014), İstanbul Avrupa Yakasındaki Okul Bahçelerinin Öğrenci Sayısına Göre Yeterliliklerinin Mekânsal Olarak Değerlendirilmesi, Yüksek Lisans Tezi, Fatih Üniversitesi Sosyal Bilimler Enstitüsü.

SCHERMERHORN JOHN, R., (1989), Management For Productivity, Third edition, John Wiley and Sons Inc., New York.

SERGIOVANNI, J. T., (1995), Schools Are Special Places, Education Week, 14 (33).

STEPHEN, P. ve CRAWLEY, T., (1994), Becoming An Effective Teacher, Cheltenham: Stanley Thornes Ltd.

SURLU, A. B. ve Ç. GÜlER., (2002), Ergonomi ve Çocuk, Standart, Yı1: 40, Sayı: 481, Ankara: DİE Yayını.

ŞAFAK, Ş., (1998), Kurumlarda Fiziksel Çevre Düzenlemesinin Önemi, I. Ulusal Kurum Ev İdaresi Kongresi, Ankara.

ŞIŞMAN, E. E. ve GÜLTÜRK, P., (2011), İlköğretim Okul Bahçelerinin Peyzaj Planlama ve Tasarım İlkeleri Açısından İncelenmesi: Tekirdağ Örneği, Tekirdağ Ziraat Fakültesi Dergisi, 8, 53-60.

TERZİOĞLU, E., (2005), İlköğretim Okulu Binalarının Fiziksel Özellikler Bakımından Değerlendirilmesi, Doktora Tezi, Hacettepe Üniversitesi, Sosyal Bilimler Enstitüsü.

THROWER, L. B., (1966), Okul ve Uygulama Bahçeleri, Çev.: Sabahattin Özbek. Ankara: Ayyıldiz Matbaacilık.

TURNER, C. E., HARRIETT B. R. ve SMITH S. L., (1970), School Health and Health Education, 6th Ed. St. Louis.

TÜRK STANDARTLARI ENSTITÜSÜ, (2000), İlköğretim Okullar1- Fiziki Yerleşim-Genel Kurallar (1. Bask1), TS 9518, Ankara.

UNESCO. (1990). Statical Yearbook. Paris: UNESCO Yayını.

UYSAL, F., (2006), Okul Öncesi Çocuk Eğitim Merkezlerinde İç ve Diş Mekan Organizasyonlarının Eğitim Yaklaşımları Çerçevesinde İncelenmesi, Yüksek Lisans Tezi, Gazi Üniversitesi, Fen Bilimleri Enstitüsü, Ankara.

UZ, M. H. ve SUR, H., (1997), Çocuk ve Çevresi I, Standart, Y1l: 36, Sayı: 426, Ankara: TSE Yayını.

ÜREY, M., (2018), Bahçe Temelli Öğrenme Yaklaşımına Yönelik Eğilimler: Okul Bahçesi Uygulamaları Örneği (2000-2015), Yüzüncü Yıl Üniversitesi Eğitim Fakültesi Dergisi,

WALlACE, H. M. vd., (1992), Principles and Practices of Student Health, School Health. Vol. 2, Third Party Pub. Co.

VELICANNGIL, S., (1975), Hekimler, Diş Hekimleri, Eczacılar ve Sağlık Mühendisleri İçin Koruyucu ve Sosyal Tip, İstanbul: Sermet Matbaası. 